\title{
The Endothelium as a Driver of Liver Fibrosis and Regeneration
}

\author{
Erica Lafoz ${ }^{1,+} \oplus$, Maria Ruart ${ }^{1,+} \oplus$, Aina Anton ${ }^{1}\left(\mathbb{D}\right.$, Anna Oncins ${ }^{1}(\mathbb{D}$ and \\ Virginia Hernández-Gea ${ }^{1,2, *(\mathbb{C})}$
}

1 Unidad de Hemodinámica Hepática, Servicio de Hepatología, Hospital Clínic, Universidad de Barcelona, Instituto de Investigaciones Biomédicas Augusto Pi Suñer (IDIBAPS), 08036 Barcelona, Spain;

LAFOZ@clinic.cat (E.L.); maria.ruart.millan@gmail.com (M.R.); anton@clinic.cat (A.A.);

aoncins@clinic.cat (A.O.)

2 Centro de Investigación Biomédica en Red de Enfermedades Hepáticas y Digestivas (CIBERehd), Instituto de Salud Carlos III, 28029 Madrid, Spain

* Correspondence: vihernandez@clinic.cat; Tel.: +34-93-227-5400 (ext. 2209)

+ Both authors share first authorship.

Received: 22 March 2020; Accepted: 6 April 2020; Published: 10 April 2020

\begin{abstract}
Liver fibrosis is a common feature of sustained liver injury and represents a major public health problem worldwide. Fibrosis is an active research field and discoveries in the last years have contributed to the development of new antifibrotic drugs, although none of them have been approved yet. Liver sinusoidal endothelial cells (LSEC) are highly specialized endothelial cells localized at the interface between the blood and other liver cell types. They lack a basement membrane and display open channels (fenestrae), making them exceptionally permeable. LSEC are the first cells affected by any kind of liver injury orchestrating the liver response to damage. LSEC govern the regenerative process initiation, but aberrant LSEC activation in chronic liver injury induces fibrosis. LSEC are also main players in fibrosis resolution. They maintain liver homeostasis and keep hepatic stellate cell and Kupffer cell quiescence. After sustained hepatic injury, they lose their phenotype and protective properties, promoting angiogenesis and vasoconstriction and contributing to inflammation and fibrosis. Therefore, improving LSEC phenotype is a promising strategy to prevent liver injury progression and complications. This review focuses on changes occurring in LSEC after liver injury and their consequences on fibrosis progression, liver regeneration, and resolution. Finally, a synopsis of the available strategies for LSEC-specific targeting is provided.
\end{abstract}

Keywords: liver; liver sinusoidal endothelial cells; LSEC; hepatic stellate cells; endothelial dysfunction; oxidative stress; inflammation; liver fibrosis resolution; liver regeneration; LSEC targeting

\section{Introduction}

Liver injury of any kind induces several molecular changes that eventually lead to the progressive fibrosis of the parenchyma and development of liver cirrhosis, the end stage of chronic liver disease. Changes at the liver endothelium level are crucial in the pathogenesis of liver fibrosis and represent the main focus of this review.

The liver has a unique vascular supply where two main venous vascular systems (portal vein and inferior cava vein) and the hepatic artery interact. Vessels ramify successively into more branches and capillaries until converging and forming a vascular network that coats the hepatic sinusoid. Liver sinusoidal endothelial cells (LSEC) are a highly specialized and distinctive micro-vascular cell type, key in the regulation of the liver microenvironment [1,2]. They are the only endothelial cells in the organism lacking a basal membrane and containing small pores called fenestrae. Fenestrae entail 
open channels that allow bidirectional blood flow between the sinusoidal blood and the hepatic cells [3,4]. LSEC are first defense barrier and contribute to hemostasis/thrombosis, metabolite transport, inflammation, angiogenesis, and vascular tone regulation. Moreover, they participate in the liver cellular response to a given injury by regulating the neighboring cells $[1,5,6]$, mainly hepatic stellate cells (HSC), the principal source of extracellular matrix (ECM) and the key player in fibrosis progression [7]. Indeed, fibrosis is the accumulation of ECM that occurs initially as a reversible wound-healing response, after acute or chronic injury, irrespective of the underlying etiology (viral infection, alcohol and metabolic injury, drug toxicity ... ) [8,9]. If the harmful stimulus is acute, ECM deposit is an attempt to limit organ damage that can be degraded when the injury is resolved. However, if the damaging stimulus exceeds the regenerative capacity of the liver and the injury persists, the response becomes excessive. Perpetuation of this "curative" response translates to fibrosis progression, substituting hepatic tissue by a fibrous scar disrupting vascular architecture and liver parenchyma $[8,10]$. Due to their privileged situation and intimate contact with the blood stream, LSEC are the first liver cell type sensing the toxic stimuli. At very initial phases, LSEC change their phenotype: lose their characteristic fenestrae and develop a basal membrane becoming a continuous endothelium, a process called capillarization. The loss of LSEC phenotype has been identified as the initial trigger to the fibrotic response [11-13].

LSEC participate in fibrosis through the secretion of angiocrine signals that act as paracrine factors balancing the liver response to injury towards fibrosis or regeneration [14].

Considering the new discoveries highlighting the role of LSEC as a principal regulator of initial response to damage, this review is divided into five sections. The first section gives a brief overview of how liver injury selectively damage LSEC. The second section focuses on the current knowledge of endothelial dysfunction, regarding how LSEC respond to injury, drives initiation and progression of fibrosis, taking into account autocrine and paracrine communication with parenchymal and non-parenchymal cells. The third section summarizes the role of LSEC in liver regeneration. The fourth section examines how LSEC are involved in fibrosis resolution. Finally, in the fifth section LSEC are presented as a potential target for therapy.

\section{Triggers for LSEC Dysfunction}

LSEC have an important role in the early response to liver injury as they orchestrate the initial response to damage of the neighboring hepatic cells. Therefore, a better understanding of the pathways involved in the initiation of the wound healing response and perpetuation of the fibrotic process are crucial to identify relevant therapeutic targets able to modify fibrosis natural history.

A wide range of LSEC noxious stimuli exist, of which ethanol [15], triglycerides and free fatty acids (FFAs) [16], hepatitis C virus (HCV) core protein [17], and HCV non-structural protein 5A (NS5A) [18] are the most common. Such stimuli trigger endothelial cell dysfunction mainly through generation of reactive oxygen species (ROS) and inflammation [19-24].

Oxidative stress is a phenomenon caused by an imbalance between the production of free radicals (species with one or more unpaired electrons), reactive metabolites, or ROS and their elimination through antioxidant mechanisms [25-27]. Oxidative stress is able to modify the phenotype of many hepatic cell types including hepatocytes, HSC, and inflammatory cells [28], but LSEC are probably the most sensitive liver cell type to oxidative stress $[29,30]$ due to several reasons: first, ROS have been described as key drivers in the initiation of liver injury and LSEC response [30-33]; second, ROS selectively damage LSEC and alter LSEC phenotype during liver injury [20,27,29]; and third, LSEC are prone to oxidative stress due to a reduction in their enzymatic detoxifying capacity of $\mathrm{H}_{2} \mathrm{O}_{2}$ [34-36]. In addition to the classical antioxidant response, LSEC have additional mechanisms, such as autophagy (a degradation process that maintains LSEC homeostasis), able to detoxify oxidative species and necessary for a proper adaptive response to stress. Indeed, recent work from our team reveals that impaired LSEC autophagy causes an improper response to oxidative damage, aggravates their phenotype, and provokes an impaired response to damage in the liver [37]. 
Oxidative stress can also be responsible for modulating the expression of pro-inflammatory cytokines and chemokines in inflammatory cells [38] initiating a robust inflammatory response [39].

Inflammation is also initiated as a result of liver damage caused by several aetiologies including infections, tissue necrosis and foreign bodies (such as lipids). Inflammatory mediators (basically IL- $\beta$ and TNF- $\alpha$ ) are released by inflammatory cells, damaged epithelial and/or endothelial cells upon injury $[24,40,41]$ that activate LSEC. Activated LSEC upregulate the expression of adhesion molecules such as selectins, vascular cell adhesion molecule-1 (VCAM-1), and intercellular adhesion molecule-1 (ICAM-1) promoting the adherence of monocytes, neutrophils, and lymphocytes. Activated LSEC also induce secretion of several cytokines, chemokines, growth factors, and eicosanoids contributing to the inflammatory response and, therefore, acquiring an inflammatory phenotype [23,24]. In addition, LSEC are able to activate the immune cascade by themselves [42-44] by activating the inflammasome [45] as they express pattern recognition receptors such as the mannose receptor, stabilins or TLR4 being able to directly sense danger-associated molecular patterns (DAMPs) or alarmins that typically originate from damaged hepatocytes (like free DNA, mitochondrial DNA, HMGB-1, IL-33, cholesterol, or FFAs) [46,47] and pathogen-associated molecular patterns (PAMPs) derived from microorganisms. Importantly, TLRs when activated are also able to activate LSEC and contribute to the release of cytokines that facilitate the progression of liver disease [23].

Inflammation per se is also able to modify LSEC vasodilatory capacity by reducing NO bioavailability and to increase ROS production by altering mitochondria permeability and fitness, altogether contributing to LSEC dysfunction [48].

\section{Endothelial Dysfunction and Fibrosis Progression}

In homeostatic conditions, LSEC are more than a fenestrated endothelium; they exhibit a vasodilatory, anti-inflammatory, anti-thrombotic, and anti-fibrotic phenotype [2]. They also regulate angiogenesis and regeneration and are very sensitive to the mechanical forces generated within the microenvironment. After a sustained hepatic injury, LSEC rapidly change their phenotype, become capillarized and acquire a pro-vasoconstrictive, pro-inflammatory, pro-thrombotic, pro-angiogenic and pro-fibrotic phenotype that impair the liver regenerative response in a process called endothelial dysfunction (Figure 1) [49-54].

Recently generated data demonstrate that endothelial dysfunction occurs prior to fibrosis initiation independently of the origin of damage [55-59]. Moreover, DeLeve and co-workers [11] verified that LSEC prevent HSC activation promoting its reversion to quiescence, suggesting that a preserved LSEC phenotype is essential to halt fibrosis progression. Interestingly, phenotypic changes in LSEC appear at early phases in dissimilar liver aetiologies such as non-alcoholic fatty liver disease (NAFLD) and alcoholic liver damage. It has also been described that LSEC dysfunction precedes Kupffer cell (KC) activation, reduction of nitric oxide content, NF-kB activation, and TNF $\alpha$, IL-6 and ICAM-1 up-regulation [56,58-62]. Therefore, a better understanding of the mechanisms implicated in the loss of LSEC functional capacity and their contribution to the initial response to damage is essential to find strategies able to halt or hamper fibrosis progression (Figure 2).

\subsection{Loss of LSEC Fenestrae}

Loss of LSEC fenestrae (capillarization) is the kickoff event in liver fibrosis. It precedes HSC activation and contributes to hepatic fibrosis and progression [11]. LSEC fenestrae are dynamic structures forming a semipermeable membrane, maintained by a cytoskeleton ring made up of actin and myosin $[63,64]$. Those fenestrae are usually open and allow the bidirectional metabolic exchange of molecules, lipoproteins, oxygen, small chylomicrons remnants and small particles between the blood and the parenchymal cells. Number and diameter of fenestra can be modulated by several factors, such as blood pressure, hormones, drugs or even changes in the ECM, among others. Substances such as serotonin, $\alpha$-adrenergic agonists and long-term ethanol abuse lead to a decreased diameter of fenestrae [65]. Narrowing of the fenestrae may impair the pass of molecules, increasing the deposition of triglyceride-rich chylomicron remnants in 
vascular beds and perpetuating liver injury. Moreover, losing fenestrae may also imply a decrease in the clearance of pharmaceutical agents and less interactions between Kupffer cells and hepatocytes.

Interestingly, defenestration is a dynamic process and it can be reverted upon removal of the trigger [65].

Capillarization is accompanied by the development of a basement membrane; LSEC lose discontinuity and become a continuous endothelium. The basement membrane created by deposition of ECM and interstitial collagen in the space of Disse also contributes to the loss and closure of fenestra [66], impeding the metabolic interchange and aggravating hepatocyte hypoxia, a potent trigger of HSC activation and fibrogenesis [54].

The exact mechanisms regulating the loss of fenestra have not been fully elucidated but several pathways have been identified. Probably the better-known mechanism controlling the LSEC phenotype is nitric oxide (NO). Indeed, several molecules and processes are able to regulate LSEC phenotype by directly controlling NO synthesis and bioavailability. Vascular endothelial growth factor (VEGF) secreted by both HSC and hepatocytes is believed to maintain LSEC phenotype via NO-dependent and NO-independent pathways $[12,67,68]$. Similarly, Krüppel-like transcription factor, Klf2, maintains a correct phenotype of LSEC up-regulating NO bioavailability [69-71]. Endothelial autophagy is also able to control NO bioavailability by regulating the antioxidant response and therefore LSEC capillarization [37]. Notch signaling is also able to promote LSEC dedifferentiation by regulating eNOS/sGC [72] and Delta-like ligand 4 (DLL4) overexpression [73].

A)
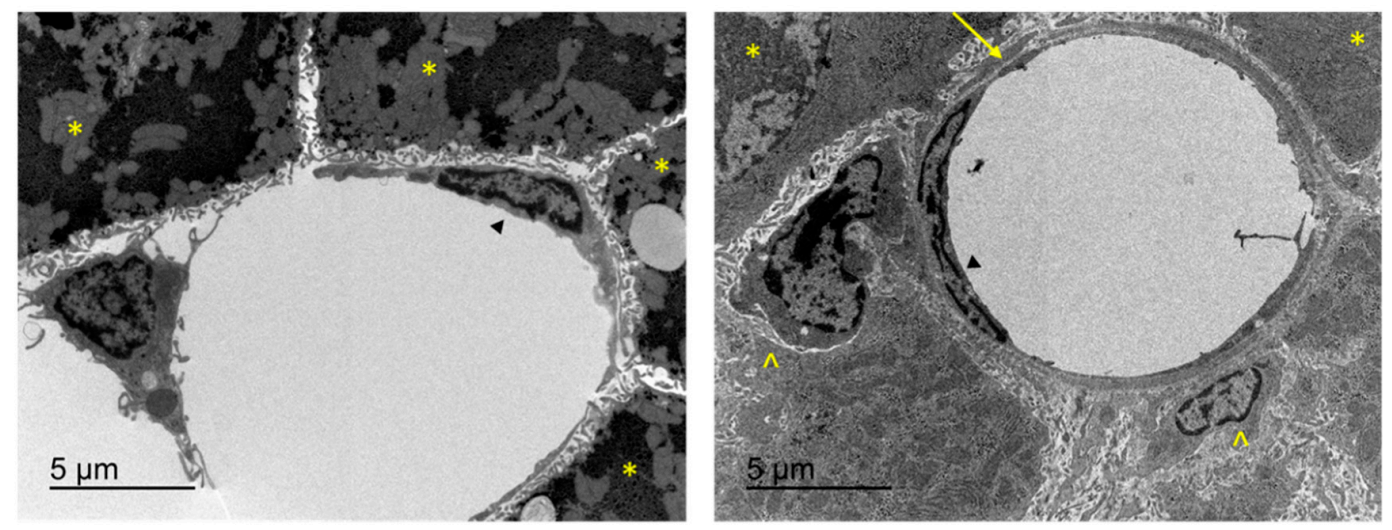

B)
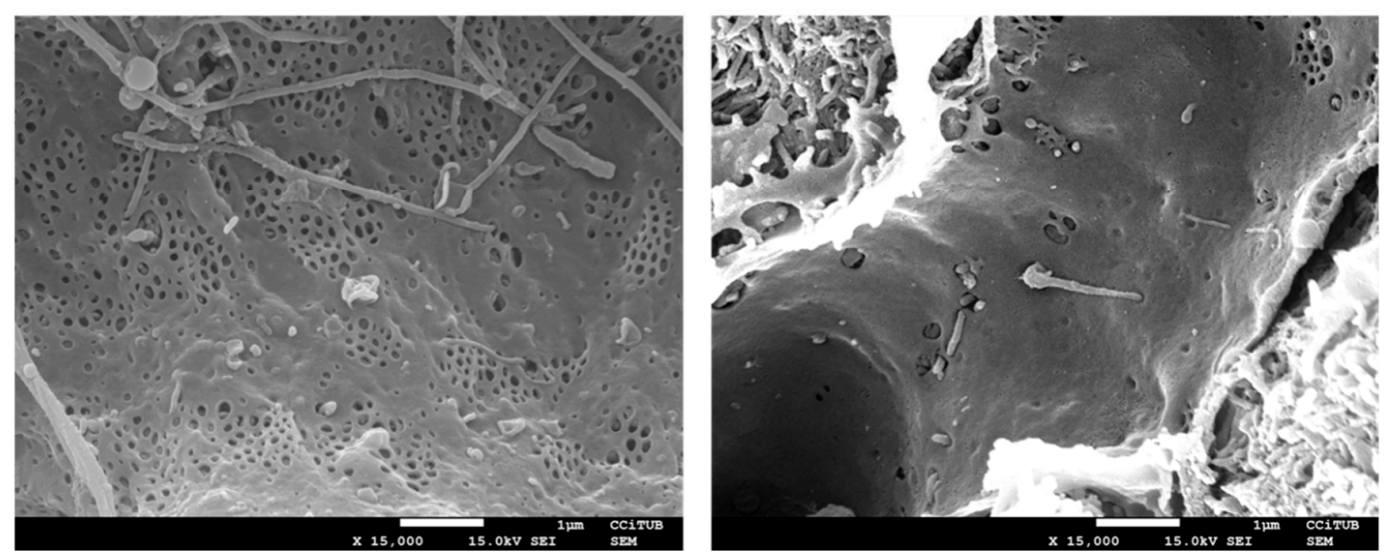

Figure 1. Structural changes in liver sinusoidal endothelial cells (LSEC) after chronic liver injury. (A) TEM images from a control liver (left) and a $\mathrm{CCl}_{4}$ induced cirrhosis (right). LSEC ( $)$ ), hepatocytes $\left(^{*}\right)$, and HSC $\left(^{\wedge}\right)$ are marked. Cirrhotic liver displays a basal membrane (arrow) which is not found in healthy liver. (B) SEM images (8000×) of fenestrae in sinusoids of healthy LSEC (left) and LSEC from $\mathrm{CCl}_{4}$ induced cirrhosis (right). LSEC from cirrhotic rats show an important loss of fenestrae in comparison with healthy rats. Original images taken by the authors from Wistar control rats (left) and $\mathrm{CCl}_{4}$ induced decompensated cirrhosis (right). 
Besides NO, Hedgehog $(\mathrm{Hh})$ signaling has also been implicated in LSEC capillarization by regulating liver X receptor (LXR) and BMP9 among others [74-79]. Although previously suggested, studies using caveolin-1 knockout mice have demonstrated that caveolin-1 has been observed in fenestrae but it is not involved in capillarization [80,81]. CD47-binding peptide of thrombospondin-1 has also been proposed as a regulator of LSEC defenestration [82].

A recent study has suggested that after a liver injury, bone marrow endothelial progenitors arrive to the site of injury and repopulate the sinusoid. However, their immature nature made them unable to develop fenestrae and maintain HSC quiescent [83].

\subsection{Loss of Vasodilatory Capacities}

One of the key events associated with endothelial dysfunction is the deregulation of the vascular tone. During liver injury, LSEC reduce their capacity to produce and respond to vasodilators, mainly NO, cyclooxygenase, and prostaglandin I2 (PGI2) $[84,85]$ and increase the production of vasoconstrictors (Endothelin1, thromboxane A2, angiotensin II) $[85,86]$. This disequilibrium does not only alter LSEC phenotype but also contributes to HSC activation [31,74,75,86-91] perpetuating its activation and contractibility $[31,84-86,92]$. Moreover, activated HSC have contractile capacity and, as they lie above the endothelium, they further increase the vascular tone $[86,92]$.

\subsection{Loss of Anti-Inflammatory Capacities}

LSEC are an integral part of the hepatic reticuloendothelial system that have a unique immunological role due to their privileged localization in intimate contact with the splanchnic blood. Under physiological conditions, the liver has a unique potential to modulate immune response, especially through tolerance induction. Its continuous exposure to bacterial-derived products from the gut induces the expression of anti-inflammatory cytokines to maintain the state of immune unresponsiveness [42-45]. However, in presence of damaging stimuli, a robust immune response can be generated and LSEC become highly proinflammatory and start secreting a vast array of cytokines and chemokines (TNF- $\alpha$, IL-6, IL-1 and CCL2) [93-95] capable of activating KC. Moreover injured hepatocytes and inflammatory cells release inflammatory mediators able to further activate LSEC and perpetuate the inflammatory response $[93,94,96]$.

Activated LSEC upregulates the cellular adhesion molecules ICAM-1, VCAM-1, and VAP-1, which recruit blood leucocytes, losing their physiological barrier capacity and leading to entry of circulating leucocytes within the liver parenchyma. LSEC are then transformed from mediators of tolerance to potent stimulators of immunity and become a critical component of intrahepatic inflammation [93,97-107].

LSEC also express MHC class I, MHC class II, ICAM-1, VCAM-1, and the costimulatory molecules CD80, CD86, and CD40 as professional antigen presenting cells (APCs) $[108,109]$ and play an important role in adaptive immunity. Antigen presentation from LSEC to CD4+ T cells promote the development of regulatory T cells (Tregs) [110]. Tregs stimulate fibrogenesis by inducing Th17 cells activation and increasing the expression of CD8+ and CD4+ T cells [111,112].

In a physiological state, antigen presentation from LSEC to CD8 T cells mediates tolerance of naïve CD8(+) T cells [108,113-117], but this response is abrogated when LSEC are exposed to high levels of antigen. During liver injury, naïve CD8 T cells are able to differentiate into effector cells [116] and to induce HSC activation and fibrogenic stimulation [118].

In addition, activated LSEC contribute to the profibrogenic response by recruiting B cells [119], natural killer T cell (NKT) cells [120] and activating KC [120-122]. Activated KC secrete a wide range of inflammatory cytokines able to sustain the inflammatory state and activate HSC. As a matter of example, TNF and IL-1 $\beta$ secretion by KC perpetuate hepatocyte injury [123] and CCL2 stimulates the infiltration of CCR2+ Ly-6Chi circulating monocytes in the liver [124,125] capable of activating and promoting HSC proliferation through the secretion of TGF $\beta 1$ and PDGF [124]. Therefore, LSEC act as effector cells promoting inflammation and are main targets of inflammatory cells contributing in both ways to amplify the fibrotic response. 


\subsection{Loss of Anti-Thrombotic Capacities}

Healthy endothelial cells express molecules that prevent platelet activation, coagulation and thrombus formation [126-130]. During endothelial dysfunction, LSEC lose their antithrombotic phenotype altering the expression of pro- and anti-thrombotic factors $[2,130,131]$. Dysfunctional LSEC expose von Willebrand factor, integrins and other receptors that interact with activated platelets, ultimately leading to blood clot formation $[132,133]$ as well as attenuating the expression of thrombomodulin, NO or PGI2 [132]. LSEC by promoting activation of the coagulation cascade and specially thrombin generation and protease-activated receptors (PARs) can induce microthrombosis and parenchymal extinction, processes linked to fibrosis progression [134-140].

Dysfunctional LSEC can also contribute to thrombosis through the recruitment of inflammatory cells. Indeed, a recent study by Hilscher et al. [141] has directly implicated LSEC in the formation of sinusoidal microthrombi through the secretion of CXCL1, which mediates neutrophil recruitment and release of neutrophil extracellular traps (NETs) in congestive hepatopathy. Additional studies are needed to evaluate whether this finding translates to other aetiologies.

\subsection{Loss of Anti-Angiogenic Capacities}

Sinusoidal capillarization together with chronic inflammation promote angiogenesis. The loss of fenestrae entails disruption of the oxygen supply and appearance of hypoxia leading to accumulation of hypoxia-inducible transcription factors (HIF) that stimulate the production of angiogenic growth factors (VEGF, FGF, angiopoetins and PDGF among others) by the surrounding cells and start new vessel formation [142,143].

Mainly in response to oxidative stress [142,144], LSEC themselves can also promote angiogenesis by directly secreting VEGF [145], TNF- $\alpha$ [142], angiopoietin 2 [146] and various types of Wnt ligands and their frizzled receptors [147].

It has been recently suggested that release of microparticles by liver cells (hepatocytes [148,149], portal myofibroblasts [150], endothelial progenitor cells [151,152], etc.) may induce angiogenesis [153]. Although the direct effects of angiogenesis on fibrosis have not been clarified yet, both processes are closely related [154]. Stimulation of angiogenesis (by deletion of the angiogenesis inhibitor prolyl-hydroxylase-2) results in liver fibrosis accumulation [155]. On the other hand, blocking angiogenesis can aggravate liver fibrosis [156] but also promote fibrosis resolution $[157,158]$ highlighting the importance of the fibrotic stage in the angiogenic response. The exact contribution of angiogenesis to fibrosis deserves further investigation.

\subsection{Loss of Anti-Fibrotic Capacities}

After a hepatic injury, LSEC themselves acquire a pro-fibrotic phenotype and participate in fibrosis by directly secreting ECM, and indirectly, regulating the hepatic microenvironment via secretion of pro-fibrotic molecules. Their direct contribution is due to the synthesis of laminin and collagen in response to TGF $\beta 1$ after sustained injury [159]. Whether endothelial cells generated from endothelial-to-mesenchymal transition [160] may contribute to ECM deposition remains a field of research.

LSEC contribute to fibrosis mainly through HSC activation. As mentioned before, LSEC regulate HSC activation via an alteration of the balance of vasodilators/vasoconstrictors molecules. LSEC also contribute to HSC activation through additional ways: secreting fibronectin EIIIA [161,162], TGF- $\beta$ and PDGF or activating signaling pathways such as Hh or Wnt $\beta$ catenin, which can activate HSC in both a paracrine and an autocrine manner [72,74-76,163-170].

Exosomes have been proposed as a novel way of intercellular communication through protein and lipid exchange [171]. The role of exosome signaling in HSC-LSEC crosstalk promoting LSEC dysfunction during liver fibrogenesis [75] has been described to be bidirectional. It has been shown that exosomes derived from dysfunctional LSEC (containing sphingosine kinase 1, SK1) regulate HSC activation and migration favoring fibrogenesis [172]. Further studies are needed to really understand the contribution of exosomes and their cargo to the fibrotic process. 


\subsection{Loss of Pro-Regenerative Capacity}

Healthy liver has the ability to regenerate after injury, but when the regenerative response is insufficient or exceeded, fibrosis develops $[173,174]$. The groundbreaking work of Ding et al. highlights the crucial role of LSEC in the liver regenerative response [175] by controlling hepatocyte proliferation. LSEC orchestrate the response of the liver microenvironment and balance regeneration over fibrosis. However, aberrant activation of LSEC in the context of chronic injury provokes the loss of their regenerative capacity and causes liver fibrosis [173,174].

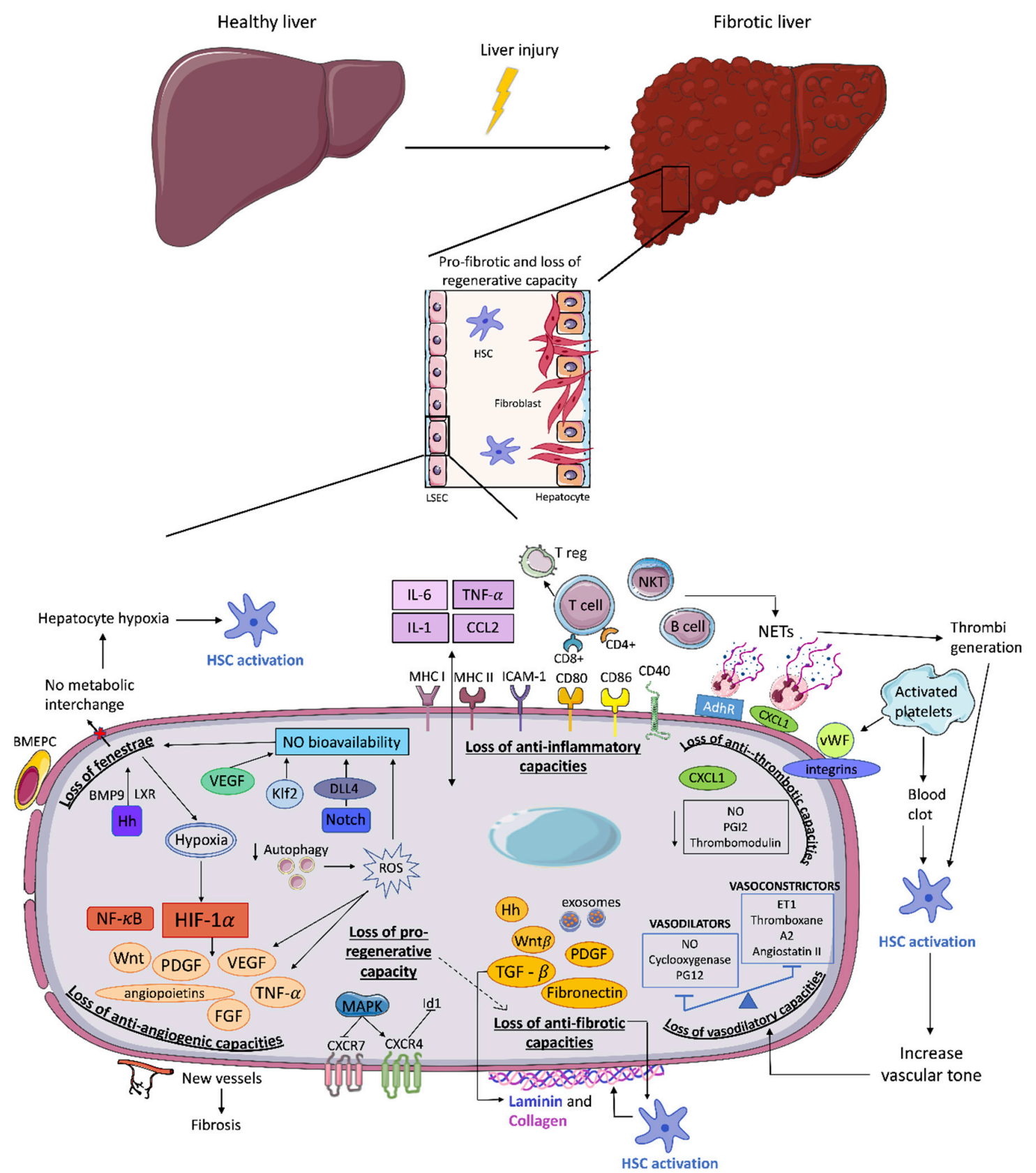

Figure 2. Changes in LSEC associated to endothelial dysfunction. After a liver injury LSEC undergo several changes: the loss of fenestrae and loss of anti-inflammatory, anti-thrombotic, anti-angiogenic, pro-regenerative, anti-fibrotic, and vasodilatory capacities leading to perpetuation of liver fibrosis and impairing liver regeneration. BMEPC: bone marrow endothelial progenitor cells; NETs: neutrophil extracellular traps; ROS: reactive oxygen species. 


\section{Effect of Mechanical Forces on LSEC Phenotype}

Mechanical forces have also arisen in the recent years as key regulators of LSEC function and phenotype.

\subsection{ECM Stiffness}

Fibrosis entails the accumulation of ECM within the liver parenchyma and increases its stiffness [176]. ECM stiffness modulates cellular behavior [177-181] and studies in vitro have demonstrated that it contributes to LSEC dysfunction by changing LSEC phenotype [182], inducing pseudocapillarization and increasing actin stress fiber formation $[96,182,183]$ and expression of adhesion molecules [182]. Therefore, increased matrix stiffness generated by HSC activation and ECM deposition can further aggravate LSEC dysfunction, perpetuating fibrosis progression [184-187].

\subsection{Shear Stress}

Physiological shear stress, the frictional force applied by blood flow on the endothelial surface [188], is also a known regulator of endothelial cell behavior and phenotype [84,189-192], in part through Klf2 expression [193-195]. Liver fibrosis is accompanied by several alterations in the vasculature, especially when portal hypertension appears (increased intrahepatic resistance, augmented portal vein flow, angiogenesis, portosystemic collaterals ... ). Although some evidences suggest that shear stress acting on LSEC following resection could be a key factor in regulating liver regeneration [196,197], the real contribution of shear stress to LSEC dysfunction and its potential therapeutic targeting remain to be elucidated.

\section{Role of LSEC Balancing Liver Regeneration and Fibrosis}

Liver regeneration involves a synchronized cooperation between parenchymal and non-parenchymal cells [198-203] where LSEC orchestrate the secretion of cytokines and growth factors necessaries for hepatocyte proliferation. At the same time, LSEC proliferation is also regulated by hepatocytes and other non-parenchymal cells $[14,165]$. During regeneration after partial hepatectomy, there are two clearly different phases; a first early/inductive phase of hepatocyte proliferation (first $48 \mathrm{~h}$ ) followed by a second phase of endothelial cell proliferation (between 72-96 h). It has been demonstrated that LSEC have a role in both phases. LSEC control the secretion of angiocrine factors such as hepatocyte growth factor (HGF), Wnt2, angiopoietin-2, fibronectin Extra Domain A and activin A $[165,175,204-214]$ during the first inductive phase, but their response to hepatocyte-derived VEGF/angiopoietin stimulation $[213,215]$ is also essential for the proliferative phase.

Sustained liver damage provokes aberrant LSEC activation and dysfunction compromising their regenerative capacity and shifting the liver response towards fibrosis [173,174] (Figure 3).

The master regulator of the regenerative response seems to be VEGF as it is able to promote hepatocyte and LSEC proliferation [213,216]. VEGF stimulates the release of HGF from LSEC through VEGFR1 promoting hepatocyte proliferation [209]. Moreover, VEGF/VEGFR2 drives regeneration depending on the Id1 pathway. Liver injury activates the CXCR7-Id1 pathway in LSEC in a VEGF dependent manner [165]. In addition, blocking Id1 impairs HGF and Wnt2 secretion by LSEC and regeneration is abrogated. Transplantation of LSEC from WT into Id1-KO mice restores their regeneration capacity after partial hepatectomy, further supporting the central role of the Id1 pathway [165]. Also in the clinical scenario of acute-on-chronic liver failure, it has been demonstrated that defects in the CXCR7-Id1 dependent HGF expression by LSEC impairs regeneration [217].

A recent paper has revealed the role of endothelial Notch in reshaping the angiocrine functions of LSEC leading to more liver fibrosis and impairing liver regeneration in mice [72]. They demonstrated that Notch activation downregulates critical hepatocyte mitogens (Wnt2a, Wnt9b, and HGF) and compromise hepatocyte proliferation. They showed that Wnt2a and Wnt9b act on an eNOS-sGC-dependent manner, but not HGF. 
The availability of the Erk1/2-Akt pathway to balance the pro-regenerative or pro-fibrotic phenotype of LSEC has also been suggested. Erk1/2 expression was associated with preservation of a pro-regenerative phenotype of LSEC and HSC quiescence through NO regulation and controlling the antioxidant response, but also via increase of the mitogens HGF and Wnt2. Indeed, Akt upregulation provoked LSEC pro-fibrotic phenotype promoting HSC activation and reducing NO, HGF, and Wnt2 expression [218].

There are several pieces of evidence that support LSEC as drivers of liver regeneration $[165,207,209]$. Apart from their paracrine functions, LSEC also participate in tissue repair by controlling the generation of new vessels. This can occur due to the extension of resident endothelial cells [219], but also due to the recruitment of bone marrow sinusoidal progenitor cells (BM SPC) that differentiate to LSEC in the site of injury, promoting neovascularization, and becoming a source of HGF [210,211,220-226]. It has been recently shown that, after several forms of liver injury or partial hepatectomy, lost or injured LSEC are not replaced by mature LSEC during regeneration but by BM SPC or sprocs [206,210,211,227,228]. Indeed, during liver regeneration, VEGF-sdf1 signaling induces proliferation in the bone marrow, mobilization to the circulation, recruitment and engraftment of CXCR7+ (sdf1 chemokine receptor or CXCL12) BM SPC. BM SPC engraft into the liver and differentiate into fenestrated LSEC through NO pathway [206,210,211].

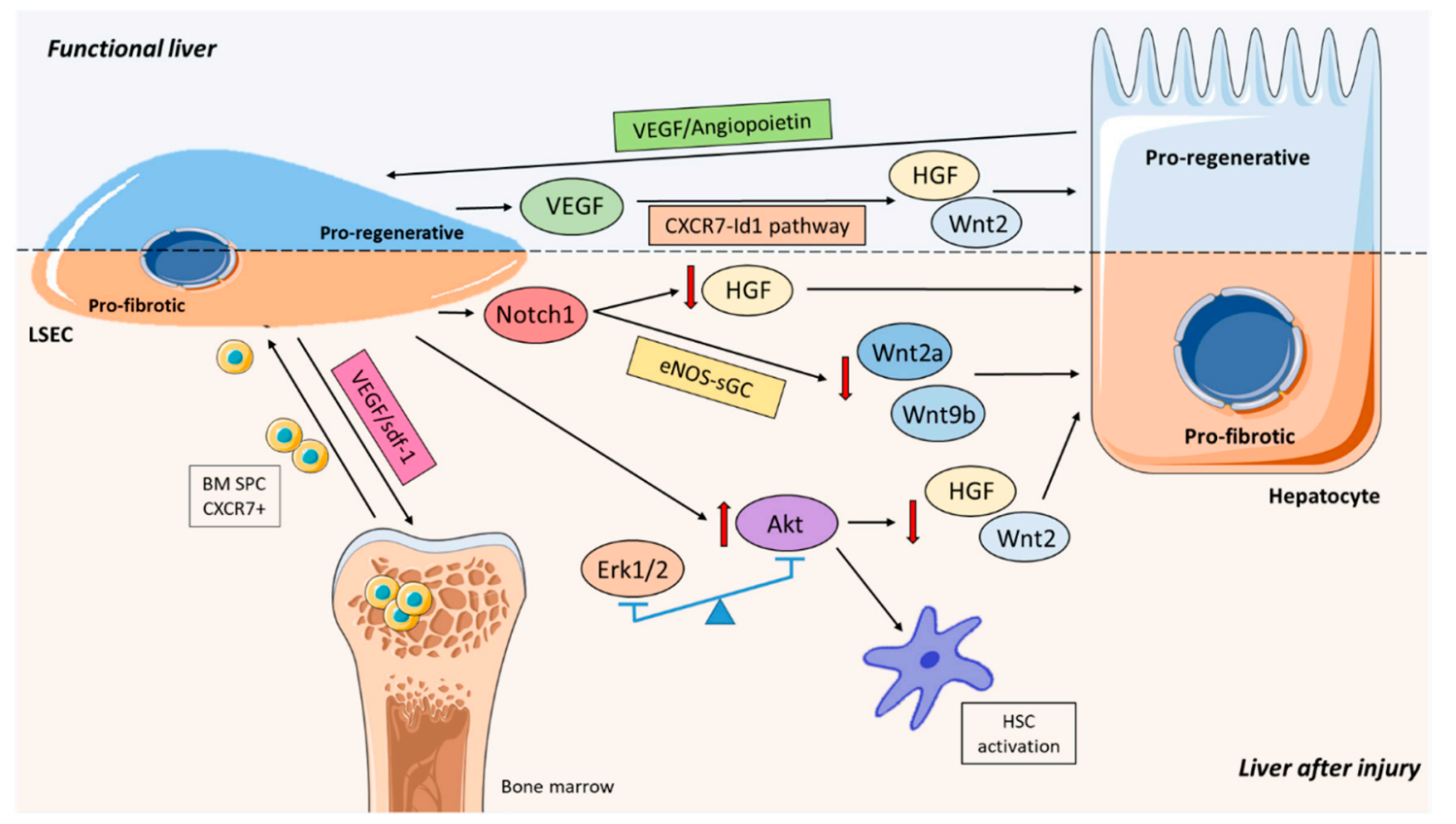

Figure 3. Main signaling pathways involving LSEC during liver regeneration. Crosstalk between hepatocytes and LSEC is crucial during regeneration. In a healthy liver, VEGF pathways induce a pro-regenerative state whereas after liver injury Notch and Akt pathways are activated leading to a pro-fibrotic phenotype. In addition, bone marrow cells (BM SPC) may be recruited by LSEC through VEGF/sdf-1 pathway and engraft in the liver.

However, to date there is considerable concern about whether BM SPC can physically incorporate into the regenerative vasculature or if they stimulate liver regeneration through secretion of paracrine factors [229-231]. In this regard, Singha and co-workers have nicely shown that depending on endothelial cell fitness, the source of regenerating liver vasculature may be different; when the endothelium is intact, neoangiogenesis is only mediated by proliferation of resident endothelial cells but after endothelial cell damage induced by irradiation, BM SPC are recruited and incorporated into the vasculature. They use multiple irradiation-based myeloablative and non-myeloablative mouse models to analyze the contribution of different cellular sources to liver regeneration after partial hepatectomy or chronic $\mathrm{CCl}_{4}$ induced liver damage and observe that BM SPC do not integrate into 
liver vasculature if there is no vascular damage. They therefore suggest that in patients with intact liver endothelial cells, BM cellular therapies will not suffice to liver regeneration [232].

There is a lot of evidence supporting the role of LSEC in coordinating the regenerative process. However, after sustained liver injury, aberrant activation of LSEC balance the liver response towards fibrosis over regeneration. LSEC dysfunction encompasses secretion of angiocrine factors that promotes fibrosis and impairs regeneration. However, the role of LSEC during neovascularization/proliferation in liver regeneration is still controversial and needs further investigation.

\section{Fibrosis Resolution}

Although fibrosis has long been considered an irreversible condition, this paradigm has changed and nowadays it is considered a dynamic and reversible process, even during advanced stages [8,233-239]. Fibrosis resolution/regression is the process that takes place after removal of the etiological agent and courses with ECM degradation and hepatocyte regeneration leading to normal or nearly normal liver histology and function [240-243]. ECM degradation is mainly directed by the balance of matrix metalloproteases (MMPs) and tissue inhibitors of MMPs (TIMPs) produced by a variety of cell types in the liver [242-245].

LSEC in particular produce VEGF [145], a key mediator in the resolution process as it facilitates liver sinusoidal permeability and recruits monocytes [157] mainly through the CXCL9-MMP13 axis. Recruitment of the monocyte-macrophage lineage, by controlling the secretion of different MMPs and TIMPs [246,247] plays a crucial role in the resolution process [248].

VEGF increases significantly during fibrosis resolution, produced by LSEC and myeloid cells [158]. VEGF fosters a LSEC pro-resolution phenotype with increased expression of MMP-2 and MMP-4, reduced expression of TIMP-1 and TIMP-2 and increased MMP-13 expression in macrophages [158,249], altogether promoting hepatic scar vascularization and fibrosis resolution. Importantly, fibrolytic properties have been attributed to LSEC that following VEGF overexpression are able to accelerate matrix degradation and improve liver regeneration [249]. Therefore VEGF may have a dual role in fibrosis; it is essential in maintaining LSEC physiological phenotype through NO regulation [250] during fibrosis onset and promote reversion of HSC activated phenotype, ameliorating LSEC dysfunction during fibrosis resolution [12].

LSEC may also contribute to the resolution process by other means. They coordinate the recruitment of many other immune cells as previously discussed such as neutrophils, directly involved in MMP secretion and matrix degradation [248]. They can also endocytose and clear denatured collagen $\alpha$ chains from blood due to their mannose receptors [251-255].

Interestingly, a recent study has shown that LSEC express AKAP12, a scaffold protein that integrates several effector proteins, after the withdrawal of fibrotic damage. This protein seems to be important during fibrosis resolution as well, as knocking it out leads to reduced fibrosis resolution [256], although the exact mechanism remains to be investigated.

\section{LSEC Targeting: Potential for Therapy}

LSEC are potent liver scavengers, able to endocytose soluble macromolecules and small particles through their numerous receptors [32,87], making them suitable for specific drug delivery. For this reason, several strategies for specific LSEC-targeting have been developed involving the use of nanoparticles, liposomes, nanoassociates, nanogels, nanocapsules or quantum dots specifically decorated, with the final aim of being directed to LSEC through the recognition of their different receptors.

Hyaluronic acid (HA) can be uptaken by LSEC via different receptors such as CD44, receptor for hyaluronate-mediated motility (RHAMM) and the HA receptor for endocytosis (HARE) or stabilin-2 [257,258]. KC are also able to uptake HA but in a much lower proportion [259]. As a result, this ligand has been explored to increase LSEC delivery by decorating cationic liposomes [259], DNA nanoassociates [260], nanocapsules [261,262] and nanogels [263]. Chondroitin sulphate is also a ligand of the scavenger receptor stabilin-2. Its use as a nanoparticle coating also effectively targets LSEC [264]. 
Serum albumin targets almost entirely stabilin-2 receptors [265]. This ligand has been used to increase LSEC delivery by coating liposomes [266], lipid particles [267] and quantum dots [268]. Apolipoprotein $\mathrm{B}$, or a part of its sequence, that is also a ligand for scavenger receptors stabilin- 1 and 2 has been used to decorate nanoparticles [269,270] and liposomes [271]. Furthermore, the polymer poly(maleic anhydride-alt-1-octadecene) has also been used to coat superparamagnetic iron oxide nanoparticles in order to direct them to the sinusoidal endothelium [272]. Besides that, adenovirus with the endothelial cell specific $\mathrm{ROBO} 4$ promoter have been seen to present a high degree of LSEC specificity and have been used to promote liver regeneration while bypassing fibrosis [218]. Finally, quantum dots (QDs), a type of nanoparticles with a size between 1-20 $\mathrm{nm}$ that present quantum effects [265] are also an area or interest [265]. Telluride/cadmium sulphide QDs [273] and Zn-labelled CdSelenide/CdS/ZnS QDs have been shown to effectively ameliorate LSEC delivery [274]. However, QDs may produce toxicity as they usually contain cadmium or other toxic elements [274].

Besides nanoparticle coating, particle size has to be taken into account since nanoparticles bigger than $250 \mathrm{~nm}$ are directly taken up by $\mathrm{KC}$ for being too big to pass through fenestrae. Contrarily, those with a diameter between 5-20nm particularly target LSEC [265,275].

For the moment, LSEC targeting strategies have been employed in the context of cancer, autoimmunity, acute liver damage, ischemia-reperfusion injury and haemophilia $[5,262,264,270,272,276]$, but they represent an attractive treatment also for liver fibrosis.

In fact, LSEC targeted delivery of drugs would represent an exceptional approach to specifically treat dysfunctional LSEC by selectively modifying their dysregulated pathways. Then, strategies that reverse endothelial dysfunction by recovering fenestrae through Notch [73] or Hh inhibition [76], anti-inflammatory capacity through vascular adhesion protein-1 (VAP-1) blockade [100] or TLR-4 inhibition [277], anti-thrombotic capacity through E-selectin/ P-selectin inhibition [133] or recombinant ADAMTS13 [278,279] delivery or anti-angiogenic capacity through angiopoietin-2 inhibition [105] or VEGF-A [280] neutralization, among others, could be specifically directed to LSEC, permitting an increased specificity and bioavailability in the cell of interest together with a reduction of the necessary dose and side effects in other organs/cells.

\section{Conclusions}

In this review, we have summarized the current knowledge about the role of LSEC as the main regulator of initial response to liver damage and their role in sinusoidal communication. The liver endothelium has a unique phenotype responsible for many of its functions. LSEC are gatekeepers of liver homeostasis because of their vasodilatory, anti-inflammatory, anti-thrombotic, anti-angiogenic, anti-fibrotic and pro-regenerative properties. Once liver injury appears, independently of the aetiology, LSEC are the first cells to sense and respond to it due to their privileged situation. A wide range of noxious stimuli can trigger LSEC loss of phenotype, mainly through the generation of ROS and inflammation. Consequently, LSEC acquire a capillarized phenotype, become pro-vasoconstrictive, pro-inflammatory, pro-thrombotic, pro-angiogenic and pro-fibrotic, and impair their liver regenerative response. Each of those phenomena has their specific contribution, promoting fibrosis progression highlighting the core contribution of LSEC in the fibrotic process.

In addition, LSEC orchestrate the liver regeneration response controlling the hepatic microenvironment by secreting paracrine factors. Aberrant activation of LSEC in the context of chronic injury promotes the loss of their regenerative capacity and balances liver response towards fibrosis over regeneration. Besides their important role in fibrosis progression, LSEC are also implicated in its resolution mainly through the secretion of VEGF and MMPs and by mediating monocyte infiltration in the liver. For all the previously stated reasons, LSEC targeting may be of enormous utility in liver fibrosis treatment. Moreover, LSEC are excellent targets for drug delivery due to their unique properties and there are many strategies able to reach LSEC and modify dysregulated pathways. Selective LSEC targeting appears as an attractive strategy to treat liver fibrosis. 
Author Contributions: Literature search, writing and revision of the manuscript, E.L. and M.R.; figure illustrations and revision of the manuscript, A.A. and A.O.; conception of the paper, writing and revision of the manuscript, V.H.-G. All authors have read and agreed to the published version of the manuscript.

Funding: Supported in part by the Instituto de Salud Carlos III (PI14/00182, PI17/00298 and PIE00027/15); FEDER "Una manera de hacer Europa"). Centro de Investigación Biomédica en Red de Enfermedades Hepáticas y Digestivas (CIBERehd) is funded by the Instituto de Salud Carlos III. EL is supported by an iPFIS grant from Instituto de Salud Carlos III (IFI17/00010). MR is supported by AGAUR-SGR2017-517 grant from Generalitat de Catalunya.

Acknowledgments: Authors acknowledge Joan Carles García- Pagán, Héctor García-Calderó, and Genís Campreciós for their scientific support. We also want to thank to SMART-Servier Medical Art for providing some of the images included in the figures.

Conflicts of Interest: The authors declare no conflicts of interest that pertain to this work.

$\begin{array}{ll}\text { Abbreviations } \\ \text { APCs } & \text { Antigen presenting cells } \\ \text { BMEPC } & \text { Bone marrow endothelial progenitor cells } \\ \text { BM SPC } & \text { Bone marrow sinusoidal progenitor cells } \\ \text { CD44 } & \text { Cluster determinant 44 } \\ \text { DAMPs } & \text { Danger-associated molecular patterns } \\ \text { DLL4 } & \text { Delta-like ligand } 4 \\ \text { ED } & \text { Endothelial dysfunction } \\ \text { ET-1 } & \text { Endothelin-1 } \\ \text { ECM } & \text { Extracellular matrix } \\ \text { FFAs } & \text { Free fatty acids } \\ \text { Hh } & \text { Hedgehog } \\ \text { HSC } & \text { Hepatic stellate cells } \\ \text { HCV } & \text { Hepatitis C virus } \\ \text { HGF } & \text { Hepatocyte growth factor } \\ \text { RHAMM } & \text { Hyaluronate-mediated motility } \\ \text { HA } & \text { Hyaluronic acid } \\ \text { HARE } & \text { Hyaluronic acid receptor for endocytosis } \\ \text { HIF } & \text { Hypoxia-inducible transcription factors } \\ \text { ICAM-1 } & \text { Intercellular adhesion molecule-1 } \\ \text { Klf2 } & \text { Krüppel-like transcription factor 2 } \\ \text { KC } & \text { Kupffer cells } \\ \text { LSEC } & \text { Liver sinusoidal endothelial cells } \\ \text { LXR } & \text { Liver } \text { X receptor } \\ \text { MMPs } & \text { Matrix metalloproteases } \\ \text { NETs } & \text { Neutrophil extracellular traps } \\ \text { NO } & \text { Nitric oxide } \\ \text { NAFLD } & \text { Non-alcoholic fatty liver disease } \\ \text { NS5A } & \text { Non-structural protein 5A } \\ \text { PAMPs } & \text { Pathogen-associated molecular patterns } \\ \text { PGI2 } & \text { Prostaglandin I2 } \\ \text { PARs } & \text { Protease-activated receptors } \\ \text { QDs } & \text { Quantum dots } \\ \text { ROS } & \text { Reactive oxygen species } \\ \text { Tregs } & \text { Regulatory T cells } \\ \text { SEM } & \text { Scanning electron microscopy } \\ \text { SK1 } & \text { Sphingosine kinase 1 } \\ \text { TIMPs } & \text { Tissue inhibitors of matrix metalloproteases } \\ \text { TEM } & \text { Transmission electron microscopy } \\ \text { VAP-1 } & \text { Vascular adhesion protein-1 } \\ & \end{array}$


VCAM-1 Vascular cell adhesion molecule-1

VEGF Vascular endothelial growth factor

VEGFR-2 Vascular endothelial growth factor receptor-2

\section{References}

1. Wisse, E.; de Zanger, R.B.; Charels, K.; van der Smissen, P.; McCuskey, R.S. The Liver Sieve: Considerations Concerning the Structure and Function of Endothelial Fenestrae, the Sinusoidal Wall and the Space of Disse. Hepatology 1985, 5, 683-692. [CrossRef] [PubMed]

2. Poisson, J.; Lemoinne, S.; Boulanger, C.; Durand, F.; Moreau, R.; Valla, D.; Rautou, P.-E. Liver Sinusoidal Endothelial Cells: Physiology and Role in Liver Diseases. J. Hepatol. 2017, 66, 212-227. [CrossRef] [PubMed]

3. Couvelard, A.; Scoazec, J.Y.; Dauge, M.C.; Bringuier, A.F.; Potet, F.; Feldmann, G. Structural and Functional Differentiation of Sinusoidal Endothelial Cells during Liver Organogenesis in Humans. Blood 1996, 87, 4568-4580. [CrossRef] [PubMed]

4. McCuskey, R.S. Morphological Mechanisms for Regulating Blood Flow through Hepatic Sinusoids. Liver Int. 2000, 20, 3-7. [CrossRef] [PubMed]

5. Tanoi, T.; Tamura, T.; Sano, N.; Nakayama, K.; Fukunaga, K.; Zheng, Y.-W.; Akhter, A.; Sakurai, Y.; Hayashi, Y.; Harashima, H.; et al. Protecting Liver Sinusoidal Endothelial Cells Suppresses Apoptosis in Acute Liver Damage. Hepatol. Res. 2016, 46, 697-706. [CrossRef] [PubMed]

6. Golse, N.; Bucur, P.O.; Adam, R.; Castaing, D.; Sa Cunha, A.; Vibert, E. New Paradigms in Post-Hepatectomy Liver Failure. J. Gastrointest. Surg. 2013, 17, 593-605. [CrossRef]

7. Bataller, R.; Brenner, D.A. Liver Fibrosis. J. Clin. Investig. 2005, 115, 209-218. [CrossRef]

8. Pellicoro, A.; Ramachandran, P.; Iredale, J.P.; Fallowfield, J.A. Liver Fibrosis and Repair: Immune Regulation of Wound Healing in a Solid Organ. Nat. Rev. Immunol. 2014, 14, 181-194. [CrossRef]

9. Povero, D.; Busletta, C.; Novo, E.; Di Bonzo, L.V.; Cannito, S.; Paternostro, C.; Parola, M. Liver Fibrosis: A Dynamic and Potentially Reversible Process. Histol. Histopathol. 2010. [CrossRef]

10. Hernandez-Gea, V.; Friedman, S.L. Pathogenesis of Liver Fibrosis. Annu. Rev. Pathol. Mech. Dis. 2011, 6, 425-456. [CrossRef]

11. DeLeve, L.D.; Wang, X.; Guo, Y. Sinusoidal Endothelial Cells Prevent Rat Stellate Cell Activation and Promote Reversion to Quiescence. Hepatology 2008, 48, 920-930. [CrossRef] [PubMed]

12. Xie, G.; Wang, X.; Wang, L.L.; Wang, L.L.; Atkinson, R.D.; Kanel, G.C.; Gaarde, W.A.; Deleve, L.D. Role of Differentiation of Liver Sinusoidal Endothelial Cells in Progression and Regression of Hepatic Fibrosis in Rats. Gastroenterology 2012, 142, 918-927.e6. [CrossRef] [PubMed]

13. Smedsrød, B.; Pertoft, H.; Gustafson, S.; Laurent, T.C. Scavenger Functions of the Liver Endothelial Cell. Biochem. J. 1990, 266, 313. [CrossRef] [PubMed]

14. Ding, B.-S.; Cao, Z.; Lis, R.; Nolan, D.J.; Guo, P.; Simons, M.; Penfold, M.E.; Shido, K.; Rabbany, S.Y.; Rafii, S. Divergent Angiocrine Signals from Vascular Niche Balance Liver Regeneration and Fibrosis. Nature 2014, 505, 97-102. [CrossRef] [PubMed]

15. Arteel, G.E. Oxidants and Antioxidants in Alcohol-Induced Liver Disease. Gastroenterology 2003, 778-790. [CrossRef] [PubMed]

16. Browning, J.D.; Horton, J.D. Molecular Mediators of Hepatic Steatosis and Liver Injury. J. Clin. Investig. 2004, 147-152. [CrossRef]

17. Okuda, M.; Li, K.; Beard, M.R.; Showalter, L.A.; Scholle, F.; Lemon, S.M.; Weinman, S.A. Mitochondrial Injury, Oxidative Stress, and Antioxidant Gene Expression Are Induced by Hepatitis C Virus Core Protein. Gastroenterology 2002, 122, 366-375. [CrossRef]

18. Gong, G.; Waris, G.; Tanveer, R.; Siddiqui, A. Human Hepatitis C Virus NS5A Protein Alters Intracellular Calcium Levels, Induces Oxidative Stress, and Activates STAT-3 and NF-KB. Proc. Natl. Acad. Sci. USA 2001, 98, 9599-9604. [CrossRef]

19. Guillaume, M.; Rodriguez-Vilarrupla, A.; Gracia-Sancho, J.; Rosado, E.; Mancini, A.; Bosch, J.; Garcia-Pagán, J.C. Recombinant Human Manganese Superoxide Dismutase Reduces Liver Fibrosis and Portal Pressure in CCl4-Cirrhotic Rats. J. Hepatol. 2013, 58, 240-246. [CrossRef] 
20. Gracia-Sancho, J.; Laviña, B.; Rodríguez-Vilarrupla, A.; García-Calderó, H.; Fernández, M.; Bosch, J.; García-Pagán, J.-C. Increased Oxidative Stress in Cirrhotic Rat Livers: A Potential Mechanism Contributing to Reduced Nitric Oxide Bioavailability. Hepatology 2008, 47, 1248-1256. [CrossRef]

21. Di Pascoli, M.; Diví, M.; Rodríguez-Vilarrupla, A.; Rosado, E.; Gracia-Sancho, J.; Vilaseca, M.; Bosch, J.; García-Pagán, J.C. Resveratrol Improves Intrahepatic Endothelial Dysfunction and Reduces Hepatic Fibrosis and Portal Pressure in Cirrhotic Rats. J. Hepatol. 2013, 58, 904-910. [CrossRef]

22. Mittal, M.; Siddiqui, M.R.; Tran, K.; Reddy, S.P.; Malik, A.B. Reactive Oxygen Species in Inflammation and Tissue Injury. Antioxid. Redox Signal. 2014. [CrossRef]

23. Del Campo, J.A.; Gallego, P.; Grande, L. Role of Inflammatory Response in Liver Diseases: Therapeutic Strategies. World J. Hepatol. 2018. [CrossRef]

24. Klatt, E.C.; Kumar, V. Tissue Renewal and Repair: Regeneration, Healing, and Fibrosis. In Robbins and Cotran Review of Pathology; Elsevier: Philadelphia, PA, USA, 2010; pp. 22-26. [CrossRef]

25. Bingol, B.; Sheng, M. Mechanisms of Mitophagy: PINK1, Parkin, USP30 and Beyond. Free Radic. Biol. Med. 2016, 100, 210-222. [CrossRef] [PubMed]

26. Tu, W.; Wang, H.; Li, S.; Liu, Q.; Sha, H. The Anti-Inflammatory and Anti-Oxidant Mechanisms of the Keap1/Nrf2/ARE Signaling Pathway in Chronic Diseases. Aging Dis. 2019, 10, 637. [CrossRef] [PubMed]

27. Rodríguez-Vilarrupla, A.; Bosch, J.; García-Pagán, J.-C. Potential Role of Antioxidants in the Treatment of Portal Hypertension. J. Hepatol. 2007, 46, 193-197. [CrossRef] [PubMed]

28. Novo, E.; Busletta, C.; Di Bonzo, L.V.; Povero, D.; Paternostro, C.; Mareschi, K.; Ferrero, I.; David, E.; Bertolani, C.; Caligiuri, A.; et al. Intracellular Reactive Oxygen Species Are Required for Directional Migration of Resident and Bone Marrow-Derived Hepatic pro-Fibrogenic Cells. J. Hepatol. 2011, 54, 964-974. [CrossRef] [PubMed]

29. Cogger, V.C.; Muller, M.; Fraser, R.; McLean, A.J.; Khan, J.; Le Couteur, D.G. The Effects of Oxidative Stress on the Liver Sieve. J. Hepatol. 2004, 41, 370-376. [CrossRef]

30. Gracia-Sancho, J.; Maeso-Díaz, R.; Fernández-Iglesias, A.; Navarro-Zornoza, M.; Bosch, J. New Cellular and Molecular Targets for the Treatment of Portal Hypertension. Hepatol. Int. 2015, 9, 183-191. [CrossRef]

31. Marrone, G.; Shah, V.H.; Gracia-Sancho, J. Sinusoidal Communication in Liver Fibrosis and Regeneration. J. Hepatol. 2016, 65, 608-617. [CrossRef]

32. Sørensen, K.K.; Simon-Santamaria, J.; McCuskey, R.S.; Smedsrød, B. Liver Sinusoidal Endothelial Cells. In Comprehensive Physiology; John Wiley \& Sons, Inc.: Hoboken, NJ, USA, 2015; Volume 5, pp. 1751-1774. [CrossRef]

33. Tsuchida, T.; Friedman, S.L. Mechanisms of Hepatic Stellate Cell Activation. Nat. Rev. Gastroenterol. Hepatol. 2017, 14, 397-411. [CrossRef] [PubMed]

34. Hamer, I.; Wattiaux, R.; Coninck, S.W.-D. Deleterious Effects of Xanthine Oxidase on Rat Liver Endothelial Cells after Ischemia/Reperfusion. Biochim. Biophys. Acta - Mol. Cell Res. 1995, 1269, 145-152. [CrossRef]

35. Deleve, L. Glutathione Defense in Non-Parenchymal Cells. Semin. Liver Dis. 1998, 18, 403-413. [CrossRef] [PubMed]

36. Mandili, G.; Alchera, E.; Merlin, S.; Imarisio, C.; Chandrashekar, B.R.; Riganti, C.; Bianchi, A.; Novelli, F.; Follenzi, A.; Carini, R. Mouse Hepatocytes and LSEC Proteome Reveal Novel Mechanisms of Ischemia/Reperfusion Damage and Protection by A2aR Stimulation. J. Hepatol. 2015, 62, 573-580. [CrossRef]

37. Ruart, M.; Chavarria, L.; Campreciós, G.; Suárez-Herrera, N.; Montironi, C.; Guixé-Muntet, S.; Bosch, J.; Friedman, S.L.; Garcia-Pagán, J.C.; Hernández-Gea, V. Impaired Endothelial Autophagy Promotes Liver Fibrosis by Aggravating the Oxidative Stress Response during Acute Liver Injury. J. Hepatol. 2019, 70, 458-469. [CrossRef]

38. Temkin, V.; Karin, M. From Death Receptor to Reactive Oxygen Species and C-Jun N-Terminal Protein Kinase: The Receptor-Interacting Protein 1 Odyssey. Immunol. Rev. 2007, 8-21. [CrossRef]

39. Friedman, S.L.; Neuschwander-Tetri, B.A.; Rinella, M.; Sanyal, A.J. Mechanisms of NAFLD Development and Therapeutic Strategies. Nat. Med. 2018. [CrossRef]

40. Tanaka, M.; Miyajima, A. Liver Regeneration and Fibrosis after Inflammation. Inflamm. Regen. 2016, 36. [CrossRef]

41. Wynn, T.A. Common and Unique Mechanisms Regulate Fibrosis in Various Fibroproliferative Diseases. J. Clin. Investig. 2007, 524-529. [CrossRef] 
42. Heymann, F.; Tacke, F. Immunology in the Liver-from Homeostasis to Disease. Nat. Rev. Gastroenterol. Hepatol. 2016. [CrossRef]

43. Crispe, I.N. The Liver as a Lymphoid Organ. Annu. Rev. Immunol. 2009, 27, 147-163. [CrossRef] [PubMed]

44. DeLeve, L.; Maretti-Mira, A. Liver Sinusoidal Endothelial Cell: An Update. Semin. Liver Dis. 2017, 37, 377-387. [CrossRef] [PubMed]

45. Boaru, S.G.; Borkham-Kamphorst, E.; Tihaa, L.; Haas, U.; Weiskirchen, R. Expression Analysis of Inflammasomes in Experimental Models of Inflammatory and Fibrotic Liver Disease. J. Inflamm. (United Kingd.) 2012. [CrossRef] [PubMed]

46. Chan, J.K.; Roth, J.; Oppenheim, J.J.; Tracey, K.J.; Vogl, T.; Feldmann, M.; Horwood, N.; Nanchahal, J. Alarmins: Awaiting a Clinical Response. J. Clin. Investig. 2012. [CrossRef] [PubMed]

47. Chen, G.Y.; Nuñez, G. Sterile Inflammation: Sensing and Reacting to Damage. Nat. Rev. Immunol. 2010. [CrossRef]

48. Sprague, A.H.; Khalil, R.A. Inflammatory Cytokines in Vascular Dysfunction and Vascular Disease. Biochem. Pharmacol. 2009, 539-552. [CrossRef] [PubMed]

49. Hickey, P.L.; Angus, P.W.; Mclean, A.J.; Morgan, D.J. Oxygen Supplementation Restores Theophylline Clearance to Normal in Cirrhotic Rats. Gastroenterology 1995, 108, 1504-1509. [CrossRef]

50. Morgan, D.J.; McLean, A.J. Therapeutic Implications of Impaired Hepatic Oxygen Diffusion in Chronic Liver Disease. Hepatology 1991, 14, 1280-1282. [CrossRef]

51. Vanheule, E.; Geerts, A.M.; Van Huysse, J.; Schelfhout, D.; Praet, M.; Van Vlierberghe, H.; De Vos, M.; Colle, I. An Intravital Microscopic Study of the Hepatic Microcirculation in Cirrhotic Mice Models: Relationship between Fibrosis and Angiogenesis. Int. J. Exp. Pathol. 2008, 89, 419-432. [CrossRef]

52. Hickey, P.L.; McLean, A.J.; Angus, P.W.; Choo, E.F.; Morgan, D.J. Increased Sensitivity of Propranolol Clearance to Reduced Oxygen Delivery in the Isolated Perfused Cirrhotic Rat Liver. Gastroenterology 1996, 111, 1039-1048. [CrossRef]

53. Braet, F.; Wisse, E. Structural and Functional Aspects of Liver Sinusoidal Endothelial Cell Fenestrae: A Review. Comp. Hepatol. 2002, 1, 1. [CrossRef] [PubMed]

54. Babbs, C.; Haboubi, N.Y.; Mellor, J.M.; Smith, A.; Rowan, B.P.; Warnes, T.W. Endothelial Cell Transformation in Primary Biliary Cirrhosis: A Morphological and Biochemical Study. Hepatology 1990, 11, 723-729. [CrossRef] [PubMed]

55. DeLeve, L.D.; Wang, X.; Kanel, G.C.; Atkinson, R.D.; McCuskey, R.S. Prevention of Hepatic Fibrosis in a Murine Model of Metabolic Syndrome with Nonalcoholic Steatohepatitis. Am. J. Pathol. 2008, 173, 993-1001. [CrossRef]

56. Horn, T.; Christoffersen, P.; Henriksen, J.H. Alcoholic Liver Injury: Defenestration in Noncirrhotic Livers-A Scanning Electron Microscopic Study. Hepatology 1987, 7, 77-82. [CrossRef] [PubMed]

57. Fraser, R.; Rogers, G.W.T.; Bowler, L.M.; Day, W.A.; Dobbs, B. Defenestration and Vitamin A Status in a Rat Model of Cirrhosis. Cells Hepatic Sinusoid 1991, 3, 195-198.

58. Francque, S.; Laleman, W.; Verbeke, L.; Van Steenkiste, C.; Casteleyn, C.; Kwanten, W.; Van Dyck, C.; D'Hondt, M.; Ramon, A.; Vermeulen, W.; et al. Increased Intrahepatic Resistance in Severe Steatosis: Endothelial Dysfunction, Vasoconstrictor Overproduction and Altered Microvascular Architecture. Lab. Investig. 2012. [CrossRef] [PubMed]

59. Pasarín, M.; La Mura, V.; Gracia-Sancho, J.; García-Calderó, H.; Rodríguez-Vilarrupla, A.; García-Pagán, J.C.; Bosch, J.; Abraldes, J.G. Sinusoidal Endothelial Dysfunction Precedes Inflammation and Fibrosis in a Model of NAFLD. PLoS ONE 2012, 7, e32785. [CrossRef]

60. Miyao, M.; Kotani, H.; Ishida, T.; Kawai, C.; Manabe, S.; Abiru, H.; Tamaki, K. Pivotal Role of Liver Sinusoidal Endothelial Cells in NAFLD/NASH Progression. Lab. Investig. 2015. [CrossRef]

61. García-Pagán, J.-C.; Gracia-Sancho, J.; Bosch, J. Functional Aspects on the Pathophysiology of Portal Hypertension in Cirrhosis. J. Hepatol. 2012, 57, 458-461. [CrossRef]

62. Tateya, S.; Rizzo, N.O.; Handa, P.; Cheng, A.M.; Morgan-Stevenson, V.; Daum, G.; Clowes, A.W.; Morton, G.J.; Schwartz, M.W.; Kim, F. Endothelial NO/CGMP/VASP Signaling Attenuates Kupffer Cell Activation and Hepatic Insulin Resistance Induced by High-Fat Feeding. Diabetes 2011, 60, 2792-2801. [CrossRef]

63. Braet, F.; de Zanger, R.; Baekeland, M.; Crabbé, E.; van der Smissen, P.; Wisse, E. Structure and Dynamics of the Fenestrae-Associated Cytoskeleton of Rat Liver Sinusoidal Endothelial Cells. Hepatology 1995. [CrossRef] 
64. Braet, F.; Spector, I.; De Zanger, R.; Wisse, E. A Novel Structure Involved in the Formation of Liver Endothelial Cell Fenestrae Revealed by Using the Actin Inhibitor Misakinolide. Proc. Natl. Acad. Sci. USA 1998. [CrossRef] [PubMed]

65. Fraser, R.; Dobbs, B.R.; Rogers, G.W.T. Lipoproteins and the Liver Sieve: The Role of the Fenestrated Sinusoidal Endothelium in Lipoprotein Metabolism, Atherosclerosis, and Cirrhosis. Hepatology 1995. [CrossRef]

66. McGuire, R.F.; Bissell, D.M.; Boyles, J.; Roll, F.J. Role of Extracellular Matrix in Regulating Fenestrations of Sinusoidal Endothelial Cells Isolated from Normal Rat Liver. Hepatology 1992. [CrossRef] [PubMed]

67. Yamane, A.; Seetharam, L.; Yamaguchi, S.; Gotoh, N.; Takahashi, T.; Neufeld, G.; Shibuya, M. A New Communication System between Hepatocytes and Sinusoidal Endothelial Cells in Liver through Vascular Endothelial Growth Factor and Flt Tyrosine Kinase Receptor Family (Flt-1 and KDR/Flk-1). Oncogene 1994, 9 , 2683-2690. [PubMed]

68. DeLeve, L.D.; Wang, X.; Hu, L.; McCuskey, M.K.; McCuskey, R.S. Rat Liver Sinusoidal Endothelial Cell Phenotype Is Maintained by Paracrine and Autocrine Regulation. Am. J. Physiol. Gastrointest. Liver Physiol. 2004, 287, G757-G763. [CrossRef] [PubMed]

69. Marrone, G.; Maeso-Díaz, R.; García-Cardena, G.; Abraldes, J.G.; García-Pagán, J.C.; Bosch, J.; Gracia-Sancho, J. KLF2 Exerts Antifibrotic and Vasoprotective Effects in Cirrhotic Rat Livers: Behind the Molecular Mechanisms of Statins. Gut 2015, 64, 1434-1443. [CrossRef]

70. Gracia-Sancho, J.; García-Calderó, H.; Hide, D.; Marrone, G.; Guixé-Muntet, S.; Peralta, C.; García-Pagán, J.C.; Abraldes, J.G.; Bosch, J. Simvastatin Maintains Function and Viability of Steatotic Rat Livers Procured for Transplantation. J. Hepatol. 2013, 58, 1140-1146. [CrossRef]

71. Guixé-Muntet, S.; de Mesquita, F.C.; Vila, S.; Hernández-Gea, V.; Peralta, C.; García-Pagán, J.C.; Bosch, J.; Gracia-Sancho, J. Cross-Talk between Autophagy and KLF2 Determines Endothelial Cell Phenotype and Microvascular Function in Acute Liver Injury. J. Hepatol. 2017, 66, 86-94. [CrossRef]

72. Duan, J.-L.L.; Ruan, B.; Yan, X.-C.C.; Liang, L.; Song, P.; Yang, Z.-Y.Y.; Liu, Y.; Dou, K.-F.F.; Han, H.; Wang, L. Endothelial Notch Activation Reshapes the Angiocrine of Sinusoidal Endothelia to Aggravate Liver Fibrosis and Blunt Regeneration in Mice. Hepatology 2018. [CrossRef]

73. Chen, L.; Gu, T.; Li, B.; Li, F.; Ma, Z.; Zhang, Q.; Cai, X.; Lu, L. Delta-like Ligand 4/DLL4 Regulates the Capillarization of Liver Sinusoidal Endothelial Cell and Liver Fibrogenesis. Biochim. Biophys. Acta Mol. Cell Res. 2019. [CrossRef] [PubMed]

74. Matz-Soja, M.; Gebhardt, R. The Many Faces of Hedgehog Signalling in the Liver: Recent Progress Reveals Striking Cellular Diversity and the Importance of Microenvironments. J. Hepatol. 2014, 61, 1449-1450. [CrossRef] [PubMed]

75. Witek, R.P.; Yang, L.; Liu, R.; Jung, Y.; Omenetti, A.; Syn, W.; Choi, S.S.; Cheong, Y.; Fearing, C.M.; Agboola, K.M.; et al. Liver Cell-Derived Microparticles Activate Hedgehog Signaling and Alter Gene Expression in Hepatic Endothelial Cells. Gastroenterology 2009, 136, 320-330.e2. [CrossRef]

76. Xie, G.; Choi, S.S.; Syn, W.-K.; Michelotti, G.A.; Swiderska, M.; Karaca, G.; Chan, I.S.; Chen, Y.; Diehl, A.M. Hedgehog Signalling Regulates Liver Sinusoidal Endothelial Cell Capillarisation. Gut 2013, 62, $299-309$. [CrossRef] [PubMed]

77. Xing, Y.; Zhao, T.; Gao, X.; Wu, Y. Liver X Receptor $\alpha$ Is Essential for the Capillarization of Liver Sinusoidal Endothelial Cells in Liver Injury. Sci. Rep. 2016. [CrossRef] [PubMed]

78. Desroches-Castan, A.; Tillet, E.; Ricard, N.; Ouarné, M.; Mallet, C.; Belmudes, L.; Couté, Y.; Boillot, O.; Scoazec, J.Y.; Bailly, S.; et al. Bone Morphogenetic Protein 9 Is a Paracrine Factor Controlling Liver Sinusoidal Endothelial Cell Fenestration and Protecting Against Hepatic Fibrosis. Hepatology 2019. [CrossRef]

79. Desroches-Castan, A.; Tillet, E.; Ricard, N.; Ouarné, M.; Mallet, C.; Feige, J.-J.; Bailly, S. Differential Consequences of Bmp9 Deletion on Sinusoidal Endothelial Cell Differentiation and Liver Fibrosis in 129/Ola and C57BL/6 Mice. Cells 2019, 8, 1079. [CrossRef]

80. Yokomori, H.; Oda, M.; Ogi, M.; Kamegaya, Y.; Tsukada, N.; Ishii, H. Endothelial Nitric Oxide Synthase and Caveolin-1 Are Co-Localized in Sinusoidal Endothelial Fenestrae. Liver 2001. [CrossRef]

81. Warren, A.; Cogger, V.C.; Arias, I.M.; McCuskey, R.S.; Le Couteur, D.G. Liver Sinusoidal Endothelial Fenestrations in Caveolin-1 Knockout Mice. Microcirculation 2010, 17, 32-38. [CrossRef]

82. Venkatraman, L.; Tucker-Kellogg, L. The CD47-Binding Peptide of Thrombospondin-1 Induces Defenestration of Liver Sinusoidal Endothelial Cells. Liver Int. 2013, 33, 1386-1397. [CrossRef] 
83. Maretti-Mira, A.C.; Wang, X.; Wang, L.; DeLeve, L.D. Incomplete Differentiation of Engrafted Bone Marrow Endothelial Progenitor Cells Initiates Hepatic Fibrosis in the Rat. Hepatology 2019. [CrossRef] [PubMed]

84. Shah, V.; Haddad, F.G.; Garcia-Cardena, G.; Frangos, J.A.; Mennone, A.; Groszmann, R.J.; Sessa, W.C. Liver Sinusoidal Endothelial Cells Are Responsible for Nitric Oxide Modulation of Resistance in the Hepatic Sinusoids. J. Clin. Investig. 1997, 100, 2923-2930. [CrossRef] [PubMed]

85. Rockey, D.C.; Chung, J.J. Reduced Nitric Oxide Production by Endothelial Cells in Cirrhotic Rat Liver: Endothelial Dysfunction in Portal Hypertension. Gastroenterology 1998, 114, 344-351. [CrossRef]

86. Gracia-Sancho, J.; Laviña, B.; Rodríguez-Vilarrupla, A.; García-Calderó, H.; Bosch, J.; García-Pagán, J.C. Enhanced Vasoconstrictor Prostanoid Production by Sinusoidal Endothelial Cells Increases Portal Perfusion Pressure in Cirrhotic Rat Livers. J. Hepatol. 2007, 47, 220-227. [CrossRef] [PubMed]

87. Sørensen, K.K.; McCourt, P.; Berg, T.; Crossley, C.; Le Couteur, D.; Wake, K.; Smedsrød, B. The Scavenger Endothelial Cell: A New Player in Homeostasis and Immunity. Am. J. Physiol. Regul. Integr. Comp. Physiol. 2012, 303, R1217-R1230. [CrossRef] [PubMed]

88. Yanagisawa, M.; Kurihara, H.; Kimura, S.; Tomobe, Y.; Kobayashi, M.; Mitsui, Y.; Yazaki, Y.; Goto, K.; Masaki, T. A Novel Potent Vasoconstrictor Peptide Produced by Vascular Endothelial Cells. Nature 1988, 332, 411-415. [CrossRef] [PubMed]

89. Bataller, R.; Sancho-Bru, P.; Ginês, P.; Brenner, D.A. Liver Fibrogenesis: A New Role for the Renin-Angiotensin System. Antioxid. Redox Signal. 2005, 7, 1346-1355. [CrossRef]

90. Rockey, D.C. Hepatic Blood Flow Regulation by Stellate Cells in Normal and Injured Liver. Semin. Liver Dis. 2001, 21, 337-350. [CrossRef]

91. Rockey, D. Vascular Mediators in the Injured Liver. Hepatology 2003, 37, 4-12. [CrossRef]

92. Rockey, D.C.; Weisiger, R.A. Endothelin Induced Contractility of Stellate Cells from Normal and Cirrhotic Rat Liver: Implications for Regulation of Portal Pressure and Resistance. Hepatology 1996, 24, 233-240. [CrossRef]

93. Feder, L.S.; Todaro, J.A.; Laskin, D.L. Characterization of Interleukin-1 and Interleukin-6 Production by Hepatic Endothelial Cells and Macrophages. J. Leukoc. Biol. 1993, 53, 126-132. [CrossRef] [PubMed]

94. Marra, F.; Tacke, F. Roles for Chemokines in Liver Disease. Gastroenterology 2014. [CrossRef] [PubMed]

95. Connolly, M.K.; Bedrosian, A.S.; Malhotra, A.; Henning, J.R.; Ibrahim, J.; Vera, V.; Cieza-Rubio, N.E.; Hassan, B.U.; Pachter, H.L.; Cohen, S.; et al. In Hepatic Fibrosis, Liver Sinusoidal Endothelial Cells Acquire Enhanced Immunogenicity. J. Immunol. 2010, 185, 2200-2208. [CrossRef] [PubMed]

96. Ford, A.J.; Jain, G.; Rajagopalan, P. Designing a Fibrotic Microenvironment to Investigate Changes in Human Liver Sinusoidal Endothelial Cell Function. Acta Biomater. 2015. [CrossRef] [PubMed]

97. Miyachi, Y.; Tsuchiya, K.; Komiya, C.; Shiba, K.; Shimazu, N.; Yamaguchi, S.; Deushi, M.; Osaka, M.; Inoue, K.; Sato, Y.; et al. Roles for Cell-Cell Adhesion and Contact in Obesity-Induced Hepatic Myeloid Cell Accumulation and Glucose Intolerance. Cell Rep. 2017, 18, 2766-2779. [CrossRef]

98. Tomita, K.; Tamiya, G.; Ando, S.; Ohsumi, K.; Chiyo, T.; Mizutani, A.; Kitamura, N.; Toda, K.; Kaneko, T.; Horie, Y.; et al. Tumour Necrosis Factor Signalling through Activation of Kupffer Cells Plays an Essential Role in Liver Fibrosis of Non-Alcoholic Steatohepatitis in Mice. Gut 2006, 55, 415-424. [CrossRef]

99. Wu, J.; Meng, Z.; Jiang, M.; Zhang, E.; Trippler, M.; Broering, R.; Bucchi, A.; Krux, F.; Dittmer, U.; Yang, D.; et al. Toll-like Receptor-Induced Innate Immune Responses in Non-Parenchymal Liver Cells Are Cell Type-Specific. Immunology 2010, 129, 363-374. [CrossRef]

100. Weston, C.J.; Shepherd, E.L.; Claridge, L.C.; Rantakari, P.; Curbishley, S.M.; Tomlinson, J.W.; Hubscher, S.G.; Reynolds, G.M.; Aalto, K.; Anstee, Q.M.; et al. Vascular Adhesion Protein-1 Promotes Liver Inflammation and Drives Hepatic Fibrosis. J. Clin. Investig. 2015, 125, 501-520. [CrossRef]

101. Shetty, S.; Lalor, P.F.; Adams, D.H. Lymphocyte Recruitment to the Liver: Molecular Insights into the Pathogenesis of Liver Injury and Hepatitis. Toxicology 2008. [CrossRef]

102. Lalor, P.F.; Hields, P.S.; Grant, A.J.; Adams, D.H. Recruitment of Lymphocytes to the Human Liver. Immunol. Cell Biol. 2002. [CrossRef]

103. Oteiza, A.; Li, R.; McCuskey, R.S.; Smedsrød, B.; Sørensen, K.K. Effects of Oxidized Low-Density Lipoproteins on the Hepatic Microvasculature. Am. J. Physiol. Liver Physiol. 2011, 301, G684-G693. [CrossRef] [PubMed]

104. van Oosten, M.; van de Bilt, E.; de Vries, H.E.; van Berkel, T.J.C.; Kuiper, J. Vascular Adhesion Molecule-1 and Intercellular Adhesion Molecule-1 Expression on Rat Liver Cells after Lipopolysaccharide Administrationin Vivo. Hepatology 1995, 22, 1538-1546. [CrossRef] [PubMed] 
105. Lefere, S.; Van de Velde, F.; Hoorens, A.; Raevens, S.; Van Campenhout, S.; Vandierendonck, A.; Neyt, S.; Vandeghinste, B.; Vanhove, C.; Debbaut, C.; et al. Angiopoietin-2 Promotes Pathological Angiogenesis and Is a Therapeutic Target in Murine Nonalcoholic Fatty Liver Disease. Hepatology 2019, 69, 1087-1104. [CrossRef]

106. Ip, E.; Farrell, G.; Hall, P.; Robertson, G.; Leclercq, I. Administration of the Potent PPAR? Agonist, Wy-14,643, Reverses Nutritional Fibrosis and Steatohepatitis in Mice. Hepatology 2004, 39, 1286-1296. [CrossRef] [PubMed]

107. dela Peña, A.; Leclercq, I.; Field, J.; George, J.; Jones, B.; Farrell, G. NF-KB Activation, Rather Than TNF, Mediates Hepatic Inflammation in a Murine Dietary Model of Steatohepatitis. Gastroenterology 2005, 129, 1663-1674. [CrossRef] [PubMed]

108. Limmer, A.; Ohl, J.; Kurts, C.; Ljunggren, H.G.; Reiss, Y.; Groettrup, M.; Momburg, F.; Arnold, B.; Knolle, P.A. Efficient Presentation of Exogenous Antigen by Liver Endothelial Cells to CD8+ T Cells Results in Antigen-Specific T-Cell Tolerance. Nat. Med. 2000, 6, 1348-1354. [CrossRef]

109. Knolle, P.A.; Schmitt, E.; Jin, S.; Germann, T.; Duchmann, R.; Hegenbarth, S.; Gerken, G.; Lohse, A.W. Induction of Cytokine Production in Naive CD4+ T Cells by Antigen- Presenting Murine Liver Sinusoidal Endothelial Cells but Failure to Induce Differentiation toward T(H1) Cells. Gastroenterology 1999, 116, 1428-1440. [CrossRef]

110. Carambia, A.; Freund, B.; Schwinge, D.; Heine, M.; Laschtowitz, A.; Huber, S.; Wraith, D.C.; Korn, T.; Schramm, C.; Lohse, A.W.; et al. TGF- $\beta$-Dependent Induction of CD $4^{+} \mathrm{CD} 25^{+}$Foxp ${ }^{+}$Tregs by Liver Sinusoidal Endothelial Cells. J. Hepatol. 2014, 61, 594-599. [CrossRef]

111. Chakraborty, K.; Chatterjee, S.; Bhattacharyya, A. Impact of Treg on Other T Cell Subsets in Progression of Fibrosis in Experimental Lung Fibrosis. Tissue Cell 2018, 53, 87-92. [CrossRef]

112. Langhans, B.; Krämer, B.; Louis, M.; Nischalke, H.D.; Hüneburg, R.; Staratschek-Jox, A.; Odenthal, M.; Manekeller, S.; Schepke, M.; Kalff, J.; et al. Intrahepatic IL-8 Producing Foxp3+CD4+ Regulatory T Cells and Fibrogenesis in Chronic Hepatitis C. J. Hepatol. 2013, 59, 229-235. [CrossRef]

113. Diehl, L.; Schurich, A.; Grochtmann, R.; Hegenbarth, S.; Chen, L.; Knolle, P.A. Tolerogenic Maturation of Liver Sinusoidal Endothelial Cells Promotes B7-Homolog 1-Dependent CD8+ T Cell Tolerance. Hepatology 2008, 47, 296-305. [CrossRef] [PubMed]

114. Limmer, A.; Ohl, J.; Wingender, G.; Berg, M.; Jüngerkes, F.; Schumak, B.; Djandji, D.; Scholz, K.; Klevenz, A.; Hegenbarth, S.; et al. Cross-Presentation of Oral Antigens by Liver Sinusoidal Endothelial Cells Leads to CD8 T Cell Tolerance. Eur. J. Immunol. 2005, 35, 2970-2981. [CrossRef] [PubMed]

115. Berg, M.; Wingender, G.; Djandji, D.; Hegenbarth, S.; Momburg, F.; Hämmerling, G.; Limmer, A.; Knolle, P. Cross-Presentation of Antigens from Apoptotic Tumor Cells by Liver Sinusoidal Endothelial Cells Leads to Tumor-Specific CD8+ T Cell Tolerance. Eur. J. Immunol. 2006, 36, 2960-2970. [CrossRef] [PubMed]

116. Schurich, A.; Berg, M.; Stabenow, D.; Böttcher, J.; Kern, M.; Schild, H.-J.; Kurts, C.; Schuette, V.; Burgdorf, S.; Diehl, L.; et al. Dynamic Regulation of CD8 T Cell Tolerance Induction by Liver Sinusoidal Endothelial Cells. J. Immunol. 2010, 184, 4107-4114. [CrossRef] [PubMed]

117. Shetty, S.; Lalor, P.F.; Adams, D.H. Liver Sinusoidal Endothelial Cells - Gatekeepers of Hepatic Immunity. Nat. Rev. Gastroenterol. Hepatol. 2018, 555-567. [CrossRef] [PubMed]

118. Safadi, R.; Ohta, M.; Alvarez, C.E.; Fiel, M.I.; Bansal, M.; Mehal, W.Z.; Friedman, S.L. Immune Stimulation of Hepatic Fibrogenesis by CD8 Cells and Attenuation by Transgenic Interleukin-10 from Hepatocytes. Gastroenterology 2004, 127, 870-882. [CrossRef]

119. Shetty, S.; Bruns, T.; Weston, C.J.; Stamataki, Z.; Oo, Y.H.; Long, H.M.; Reynolds, G.M.; Pratt, G.; Moss, P.; Jalkanen, S.; et al. Recruitment Mechanisms of Primary and Malignant B Cells to the Human Liver. Hepatology 2012, 56, 1521-1531. [CrossRef]

120. Wehr, A.; Baeck, C.; Heymann, F.; Niemietz, P.M.; Hammerich, L.; Martin, C.; Zimmermann, H.W.; Pack, O.; Gassler, N.; Hittatiya, K.; et al. Chemokine Receptor CXCR6-Dependent Hepatic NK T Cell Accumulation Promotes Inflammation and Liver Fibrosis. J. Immunol. 2013, 190, 5226-5236. [CrossRef]

121. Novobrantseva, T.I.; Majeau, G.R.; Amatucci, A.; Kogan, S.; Brenner, I.; Casola, S.; Shlomchik, M.J.; Koteliansky, V.; Hochman, P.S.; Ibraghimov, A. Attenuated Liver Fibrosis in the Absence of B Cells. J. Clin. Investig. 2005, 115, 3072-3082. [CrossRef]

122. Thapa, M.; Chinnadurai, R.; Velazquez, V.M.; Tedesco, D.; Elrod, E.; Han, J.H.; Sharma, P.; Ibegbu, C.; Gewirtz, A.; Anania, F.; et al. Liver Fibrosis Occurs through Dysregulation of MyD88-Dependent Innate B-Cell Activity. Hepatology 2015, 61, 2067-2079. [CrossRef] 
123. Ju, C.; Tacke, F. Hepatic Macrophages in Homeostasis and Liver Diseases: From Pathogenesis to Novel Therapeutic Strategies. Cell. Mol. Immunol. 2016. [CrossRef] [PubMed]

124. Tacke, F. Targeting Hepatic Macrophages to Treat Liver Diseases. J. Hepatol. 2017, 66, 1300-1312. [CrossRef]

125. Parola, M.; Pinzani, M. Liver Fibrosis: Pathophysiology, Pathogenetic Targets and Clinical Issues. Mol. Asp. Med. 2019, 37-55. [CrossRef] [PubMed]

126. Colburn, P.; Buonassisi, V. Anti-Clotting Activity of Endothelial Cell Cultures and Heparan Sulfate Proteoglycans. Biochem. Biophys. Res. Commun. 1982, 104, 220-227. [CrossRef]

127. Moncada, S.; Gryglewski, R.; Bunting, S.; Vane, J.R. An Enzyme Isolated from Arteries Transforms Prostaglandin Endoperoxides to an Unstable Substance That Inhibits Platelet Aggregation. Nature 1976, 263, 663-665. [CrossRef] [PubMed]

128. Mellion, B.T.; Ignarro, L.J.; Ohlstein, E.H.; Pontecorvo, E.G.; Hyman, A.L.; Kadowitz, P.J. Evidence for the Inhibitory Role of Guanosine 3',5'-Monophosphate in ADP-Induced Human Platelet Aggregation in the Presence of Nitric Oxide and Related Vasodilators. Blood 1981, 57, 946-955. [CrossRef]

129. Radomski, M.W.; Palmer, R.M.J.; Moncada, S. ENDOGENOUS NITRIC OXIDE INHIBITS HUMAN PLATELET ADHESION TO VASCULAR ENDOTHELIUM. Lancet 1987, 330, 1057-1058. [CrossRef]

130. Bochenek, M.L.; Schäfer, K. Role of Endothelial Cells in Acute and Chronic Thrombosis. Hamostaseologie 2019, 128-139. [CrossRef]

131. Esmon, C.T. Basic Mechanisms and Pathogenesis of Venous Thrombosis. Blood Rev. 2009, 23, $225-229$. [CrossRef]

132. Bevilacqua, M.P.; Pober, J.S.; Majeau, G.R.; Cotran, R.S.; Gimbrone, M.A. Interleukin 1 (IL-1) Induces Biosynthesis and Cell Surface Expression of Procoagulant Activity in Human Vascular Endothelial Cells. J. Exp. Med. 1984, 160, 618-623. [CrossRef]

133. Myers, D.; Farris, D.; Hawley, A.; Wrobleski, S.; Chapman, A.; Stoolman, L.; Knibbs, R.; Strieter, R.; Wakefield, T. Selectins Influence Thrombosis in a Mouse Model of Experimental Deep Venous Thrombosis. J. Surg. Res. 2002, 108, 212-221. [CrossRef] [PubMed]

134. Wanless, I.R.; Liu, J.J.; Butany, J. Role of Thrombosis in the Pathogenesis of Congestive Hepatic Fibrosis (Cardiac Cirrhosis). Hepatology 1995, 21, 1232-1237. [CrossRef] [PubMed]

135. Wanless, I.R.; Wong, F.; Blendis, L.M.; Greig, P.; Heathcote, E.J.; Levy, G. Hepatic and Portal Vein Thrombosis in Cirrhosis: Possible Role in Development of Parenchymal Extinction and Portal Hypertension. Hepatology 1995, 21, 1238-1247. [CrossRef] [PubMed]

136. Anstee, Q.M.; Wright, M.; Goldin, R.; Thursz, M.R. Parenchymal Extinction: Coagulation and Hepatic Fibrogenesis. Clin. Liver Disease 2009, 117-126. [CrossRef]

137. Cerini, F.; Vilaseca, M.; Lafoz, E.; García-Irigoyen, O.; García-Calderó, H.; Tripathi, D.M.; Avila, M.; Reverter, J.C.; Bosch, J.; Gracia-Sancho, J.; et al. Enoxaparin Reduces Hepatic Vascular Resistance and Portal Pressure in Cirrhotic Rats. J. Hepatol. 2016, 64. [CrossRef]

138. Chambers, R.C.; Dabbagh, K.; McAnulty, R.J.; Gray, A.J.; Blanc-Brude, O.P.; Laurent, G.J. Thrombin Stimulates Fibroblast Procollagen Production via Proteolytic Activation of Protease-Activated Receptor 1. Biochem. J. 1998, 333, 121-127. [CrossRef]

139. Gaça, M.D.A.; Zhou, X.; Benyon, R.C. Regulation of Hepatic Stellate Cell Proliferation and Collagen Synthesis by Proteinase-Activated Receptors. J. Hepatol. 2002, 36, 362-369. [CrossRef]

140. Fiorucci, S.; Antonelli, E.; Distrutti, E.; Severino, B.; Fiorentina, R.; Baldoni, M.; Caliendo, G.; Santagada, V.; Morelli, A.; Cirino, G. PAR1 Antagonism Protects Against Experimental Liver Fibrosis. Role of Proteinase Receptors in Stellate Cell Activation. Hepatology 2004, 39, 365-375. [CrossRef]

141. Hilscher, M.B.; Sehrawat, T.; Arab, J.P.; Zeng, Z.; Gao, J.; Liu, M.; Kostallari, E.; Gao, Y.; Simonetto, D.A.; Yaqoob, U.; et al. Mechanical Stretch Increases Expression of CXCL1 in Liver Sinusoidal Endothelial Cells to Recruit Neutrophils, Generate Sinusoidal Microthombi, and Promote Portal Hypertension. Gastroenterology 2019, 157, 193-209.e9. [CrossRef]

142. Coulon, S.; Heindryckx, F.; Geerts, A.; Van Steenkiste, C.; Colle, I.; Van Vlierberghe, H. Angiogenesis in Chronic Liver Disease and Its Complications. Liver Int. 2011, 146-162. [CrossRef]

143. Carmeliet, P.; Jain, R.K. Molecular Mechanisms and Clinical Applications of Angiogenesis. Nature 2011, 298-307. [CrossRef]

144. Dewhirst, M.W.; Cao, Y.; Moeller, B. Cycling Hypoxia and Free Radicals Regulate Angiogenesis and Radiotherapy Response. Nat. Rev. Cancer 2008, 425-437. [CrossRef] 
145. Semela, D.; Das, A.; Langer, D.; Kang, N.; Leof, E.; Shah, V. PDGF Signaling through Ephrin-B2 Regulates Hepatic Vascular Structure and Function. Gastroenterology 2009, 135, 671-679. [CrossRef]

146. Augustin, H.G.; Young Koh, G.; Thurston, G.; Alitalo, K. Control of Vascular Morphogenesis and Homeostasis through the Angiopoietin - Tie System. Nat. Rev. Mol. Cell Biol. 2009, 165-177. [CrossRef]

147. Phng, L.K.; Potente, M.; Leslie, J.D.; Babbage, J.; Nyqvist, D.; Lobov, I.; Ondr, J.K.; Rao, S.; Lang, R.A.; Thurston, G.; et al. Nrarp Coordinates Endothelial Notch and Wnt Signaling to Control Vessel Density in Angiogenesis. Dev. Cell 2009, 16, 70-82. [CrossRef]

148. Povero, D.; Eguchi, A.; Niesman, I.R.; Andronikou, N.; Du Jeu, X.D.M.; Mulya, A.; Berk, M.; Lazic, M.; Thapaliya, S.; Parola, M.; et al. Lipid-Induced Toxicity Stimulates Hepatocytes to Release Angiogenic Microparticles That Require Vanin-1 for Uptake by Endothelial Cells. Sci. Signal. 2013, 6. [CrossRef]

149. Povero, D.; Panera, N.; Eguchi, A.; Johnson, C.D.; Papouchado, B.G.; de Araujo Horcel, L.; Pinatel, E.M.; Alisi, A.; Nobili, V.; Feldstein, A.E. Lipid-Induced Hepatocyte-Derived Extracellular Vesicles Regulate Hepatic Stellate Cells via MicroRNA Targeting Peroxisome Proliferator-Activated Receptor- $\gamma$. CMGH 2015, 1, 646-663.e4. [CrossRef]

150. Lemoinne, S.; Cadoret, A.; Rautou, P.E.; El Mourabit, H.; Ratziu, V.; Corpechot, C.; Rey, C.; Bosselut, N.; Barbu, V.; Wendum, D.; et al. Portal Myofibroblasts Promote Vascular Remodeling Underlying Cirrhosis Formation through the Release of Microparticles. Hepatology 2015, 61, 1041-1055. [CrossRef]

151. Deregibus, M.C.; Cantaluppi, V.; Calogero, R.; Lo Iacono, M.; Tetta, C.; Biancone, L.; Bruno, S.; Bussolati, B.; Camussi, G. Endothelial Progenitor Cell - Derived Microvesicles Activate an Angiogenic Program in Endothelial Cells by a Horizontal Transfer of MRNA. Blood 2007, 110, 2440-2448. [CrossRef]

152. Mause, S.F.; Ritzel, E.; Liehn, E.A.; Hristov, M.; Bidzhekov, K.; Müller-Newen, G.; Soehnlein, O.; Weber, C. Platelet Microparticles Enhance the Vasoregenerative Potential of Angiogenic Early Outgrowth Cells after Vascular Injury. Circulation 2010, 122, 495-506. [CrossRef]

153. Kitade, M.; Yoshiji, H.; Kojima, H.; Ikenaka, Y.; Noguchi, R.; Kaji, K.; Yoshii, J.; Yanase, K.; Namisaki, T.; Asada, K.; et al. Leptin-Mediated Neovascularization Is a Prerequisite for Progression of Nonalcoholic Steatohepatitis in Rats. Hepatology 2006, 44, 983-991. [CrossRef]

154. Ehling, J.; Bartneck, M.; Wei, X.; Gremse, F.; Fech, V.; Möckel, D.; Baeck, C.; Hittatiya, K.; Eulberg, D.; Luedde, T.; et al. CCL2-Dependent Infiltrating Macrophages Promote Angiogenesis in Progressive Liver Fibrosis. Gut 2014, 63, 1960-1971. [CrossRef]

155. Zhou, L.Y.; Zeng, H.; Wang, S.; Chen, J.X. Regulatory Role of Endothelial PHD2 in the Hepatic Steatosis. Cell. Physiol. Biochem. 2018, 48, 1003-1011. [CrossRef]

156. Patsenker, E.; Popov, Y.; Stickel, F.; Schneider, V.; Ledermann, M.; Sägesser, H.; Niedobitek, G.; Goodman, S.L.; Schuppan, D. Pharmacological Inhibition of Integrin Av $\beta 3$ Aggravates Experimental Liver Fibrosis and Suppresses Hepatic Angiogenesis. Hepatology 2009, 50, 1501-1511. [CrossRef]

157. Yang, L.; Kwon, J.; Popov, Y.; Gajdos, G.B.; Ordog, T.; Brekken, R.A.; Mukhopadhyay, D.; Schuppan, D.; Bi, Y.; Simonetto, D.; et al. Vascular Endothelial Growth Factor Promotes Fibrosis Resolution and Repair in Mice. Gastroenterology 2014, 146. [CrossRef]

158. Kantari-Mimoun, C.; Castells, M.; Klose, R.; Meinecke, A.K.; Lemberger, U.J.; Rautou, P.E.; Pinot-Roussel, H.; Badoual, C.; Schrödter, K.; Österreicher, C.H.; et al. Resolution of Liver Fibrosis Requires Myeloid Cell-Driven Sinusoidal Angiogenesis. Hepatology 2015, 61, 2042-2055. [CrossRef]

159. Neubauer, K.; Krüger, M.; Quondamatteo, F.; Knittel, T.; Saile, B.; Ramadori, G. Transforming Growth Factor-B1 Stimulates the Synthesis of Basement Membrane Proteins Laminin, Collagen Type IV and Entactin in Rat Liver Sinusoidal Endothelial Cells. J. Hepatol. 1999, 31, 692-702. [CrossRef]

160. Ribera, J.; Pauta, M.; Melgar-Lesmes, P.; Córdoba, B.; Bosch, A.; Calvo, M.; Rodrigo-Torres, D.; Sancho-Bru, P.; Mira, A.; Jiménez, W.; et al. A Small Population of Liver Endothelial Cells Undergoes Endothelial-Tomesenchymal Transition in Response to Chronic Liver Injury. Am. J. Physiol. Gastrointest. Liver Physiol. 2017. [CrossRef]

161. Jarnagin, W.R.; Rockey, D.C.; Koteliansky, V.E.; Wang, S.S.; Bissell, D.M. Expression of Variant Fibronectins in Wound Healing: Cellular Source and Biological Activity of the EIIIA Segment in Rat Hepatic Fibrogenesis. J. Cell Biol. 1994, 127, 2037-2048. [CrossRef]

162. Friedman, S.L. Liver Fibrosis - From Bench to Bedside. J. Hepatol. 2003. [CrossRef]

163. Wang, B.; Zhao, L.; Fish, M.; Logan, C.Y.; Nusse, R. Self-Renewing Diploid Axin2+ Cells Fuel Homeostatic Renewal of the Liver. Nature 2015, 524, 180. [CrossRef] 
164. Sakata, K.; Eda, S.; Lee, E.-S.; Hara, M.; Imoto, M.; Kojima, S. Neovessel Formation Promotes Liver Fibrosis via Providing Latent Transforming Growth Factor- $\beta$. Biochem. Biophys. Res. Commun. 2014, 443, 950-956. [CrossRef]

165. Ding, B.-S.; Nolan, D.J.; Butler, J.M.; James, D.; Babazadeh, A.O.; Rosenwaks, Z.; Mittal, V.; Kobayashi, H.; Shido, K.; Lyden, D.; et al. Inductive Angiocrine Signals from Sinusoidal Endothelium Are Required for Liver Regeneration. Nature 2010, 468, 310-315. [CrossRef]

166. Glińska-Suchocka, K.; Orłowska, A.; Spużak, J.; Jankowski, M.; Kubiak, K. Suitability of Using Serum Hialuronic Acid Concentrations in the Diagnosis of Canine Liver Fibrosis. Pol. J. Vet. Sci. 2015, 18, 873-878. [CrossRef]

167. Baranova, A.; Lal, P.; Birerdinc, A.; Younossi, Z.M. Non-Invasive Markers for Hepatic Fibrosis. BMC Gastroenterol. 2011, 11, 91. [CrossRef]

168. Wong, L.; Yamasaki, G.; Johnson, R.J.; Friedman, S.L. Induction of Beta-Platelet-Derived Growth Factor Receptor in Rat Hepatic Lipocytes during Cellular Activation in Vivo and in Culture. J. Clin. Investig. 1994, 94, 1563-1569. [CrossRef]

169. Sato, Y.; Okada, F.; Abe, M.; Seguchi, T.; Kuwano, M.; Sato, S.; Furuya, A.; Hanai, N.; Tamaoki, T. The Mechanism for the Activation of Latent TGF-Beta during Co-Culture of Endothelial Cells and Smooth Muscle Cells: Cell-Type Specific Targeting of Latent TGF-Beta to Smooth Muscle Cells. J. Cell Biol. 1993, 123, 1249-1254. [CrossRef]

170. Rocha, A.S.; Vidal, V.; Mertz, M.; Kendall, T.J.; Charlet, A.; Okamoto, H.; Schedl, A. The Angiocrine Factor Rspondin3 Is a Key Determinant of Liver Zonation. Cell Rep. 2015, 13, 1757-1764. [CrossRef]

171. Théry, C.; Amigorena, S.; Raposo, G.; Clayton, A. Isolation and Characterization of Exosomes from Cell Culture Supernatants and Biological Fluids. Curr. Protoc. Cell Biol. 2006. [CrossRef]

172. Wang, R.; Ding, Q.; Yaqoob, U.; De Assuncao, T.D.M.; Verma, V.K.; Hirsova, P.; Cao, S.; Mukhopadhyay, D.; Huebert, R.C.; Shah, V.H. Exosome Adherence and Internalization by Hepatic Stellate Cells Triggers Sphingosine 1-Phosphate-Dependent Migration. J. Biol. Chem. 2015. [CrossRef]

173. Kuramitsu, K.; Sverdlov, D.Y.; Liu, S.B.; Csizmadia, E.; Burkly, L.; Schuppan, D.; Hanto, D.W.; Otterbein, L.E.; Popov, Y. Failure of Fibrotic Liver Regeneration in Mice Is Linked to a Severe Fibrogenic Response Driven by Hepatic Progenitor Cell Activation. Am. J. Pathol. 2013. [CrossRef]

174. Cordero-Espinoza, L.; Huch, M. The Balancing Act of the Liver: Tissue Regeneration versus Fibrosis. J. Clin. Investig. 2018. [CrossRef] [PubMed]

175. Greene, A.K.; Wiener, S.; Puder, M.; Yoshida, A.; Shi, B.; Perez-Atayde, A.R.; Efstathiou, J.A.; Holmgren, L.; Adamis, A.P.; Rupnick, M.; et al. Endothelial-Directed Hepatic Regeneration after Partial Hepatectomy. Ann. Surg. 2003. [CrossRef] [PubMed]

176. Foucher, J.; Chanteloup, E.; Vergniol, J.; Castéra, L.; Le Bail, B.; Adhoute, X.; Bertet, J.; Couzigou, P.; De Lédinghen, V. Diagnosis of Cirrhosis by Transient Elastography (FibroScan): A Prospective Study. Gut 2006, 55, 403-408. [CrossRef] [PubMed]

177. Wells, R.G. The Role of Matrix Stiffness in Regulating Cell Behavior. Hepatology 2008, 1394-1400. [CrossRef]

178. Olsen, A.L.; Bloomer, S.A.; Chan, E.P.; Gaça, M.D.A.; Georges, P.C.; Sackey, B.; Uemura, M.; Janmey, P.A.; Wells, R.G. Hepatic Stellate Cells Require a Stiff Environment for Myofibroblastic Differentiation. Am. J. Physiol. Gastrointest. Liver Physiol. 2011, 301. [CrossRef]

179. Wells, R.G. The Role of Matrix Stiffness in Hepatic Stellate Cell Activation and Liver Fibrosis. J. Clin. Gastroenterol. 2005. [CrossRef]

180. Natarajan, V.; Berglund, E.J.; Chen, D.X.; Kidambi, S. Substrate Stiffness Regulates Primary Hepatocyte Functions. RSC Adv. 2015, 5, 80956-80966. [CrossRef]

181. Desai, S.S.; Tung, J.C.; Zhou, V.X.; Grenert, J.P.; Malato, Y.; Rezvani, M.; Español-Suñer, R.; Willenbring, H.; Weaver, V.M.; Chang, T.T. Physiological Ranges of Matrix Rigidity Modulate Primary Mouse Hepatocyte Function in Part through Hepatocyte Nuclear Factor 4 Alpha. Hepatology 2016, 64, 261-275. [CrossRef]

182. Matrix Stiffness Regulate Liver Sinusoidal Endothelial Cells (LSECs) Function: Importance for Liver Fibrosis Progression. Available online: https://www.fasebj.org/doi/abs/10.1096/fasebj.2019.33.1_supplement.496.39 (accessed on 24 October 2019).

183. Juin, A.; Planus, E.; Guillemot, F.; Horakova, P.; Albiges-Rizo, C.; Génot, E.; Rosenbaum, J.; Moreau, V.; Saltel, F. Extracellular Matrix Rigidity Controls Podosome Induction in Microvascular Endothelial Cells. Biol. Cell 2013, 105, 46-57. [CrossRef] 
184. Kilarski, W.W.; Samolov, B.; Petersson, L.; Kvanta, A.; Gerwins, P. Biomechanical Regulation of Blood Vessel Growth during Tissue Vascularization. Nat. Med. 2009, 15, 657-664. [CrossRef]

185. Korff, T.; Augustin, H.G. Tensional Forces in Fibrillar Extracellular Matrices Control Directional Capillary Sprouting. J. Cell Sci. 1999, 112, 3249-3258. [PubMed]

186. Bishop, P.N. The Role of Extracellular Matrix in Retinal Vascular Development and Preretinal Neovascularization. Exp. Eye Res. 2015, 133, 30-36. [CrossRef] [PubMed]

187. Liu, L.; You, Z.; Yu, H.; Zhou, L.; Zhao, H.; Yan, X.; Li, D.; Wang, B.; Zhu, L.; Xu, Y.; et al. Mechanotransduction-Modulated Fibrotic Microniches Reveal the Contribution of Angiogenesis in Liver Fibrosis. Nat. Mater. 2017, 16, 1252-1261. [CrossRef] [PubMed]

188. Davies, P.F. Flow-Mediated Endothelial Mechanotransduction. Physiol. Rev. 1995, 519-560. [CrossRef] [PubMed]

189. Ayajiki, K.; Kindermann, M.; Hecker, M.; Fleming, I.; Busse, R. Intracellular PH and Tyrosine Phosphorylation but Not Calcium Determine Shear Stress-Induced Nitric Oxide Production in Native Endothelial Cells. Circ. Res. 1996, 78, 750-758. [CrossRef]

190. Hwa, A.J.; Fry, R.C.; Sivaraman, A.; So, P.T.; Samson, L.D.; Stolz, D.B.; Griffith, L.G. Rat Liver Sinusoidal Endothelial Cells Survive without Exogenous VEGF in 3D Perfused Co-Cultures with Hepatocytes. FASEB J. 2007, 21, 2564-2579. [CrossRef]

191. Domansky, K.; Inman, W.; Serdy, J.; Dash, A.; Lim, M.H.M.; Griffith, L.G. Perfused Multiwell Plate for 3D Liver Tissue Engineering. Lab Chip 2010, 10, 51-58. [CrossRef]

192. Ortega-Ribera, M.; Fernández-Iglesias, A.; Illa, X.; Moya, A.; Molina, V.; Maeso-Díaz, R.; Fondevila, C.; Peralta, C.; Bosch, J.; Villa, R.; et al. Resemblance of the Human Liver Sinusoid in a Fluidic Device with Biomedical and Pharmaceutical Applications. Biotechnol. Bioeng. 2018, 115, 2585-2594. [CrossRef]

193. Parmar, K.M.; Larman, H.B.; Dai, G.; Zhang, Y.; Wang, E.T.; Moorthy, S.N.; Kratz, J.R.; Lin, Z.; Jain, M.K.; Gimbrone, M.A.; et al. Integration of Flow-Dependent Endothelial Phenotypes by Kruppel-like Factor 2. J. Clin. Investig. 2006, 116, 49-58. [CrossRef]

194. Gracia-Sancho, J.; Villarreal, G.; Zhang, Y.; Yu, J.X.; Liu, Y.; Tullius, S.G.; García-Cardeña, G. Flow Cessation Triggers Endothelial Dysfunction during Organ Cold Storage Conditions: Strategies for Pharmacologic Intervention. Transplantation 2010, 90, 142-149. [CrossRef]

195. Marrone, G.; Russo, L.; Rosado, E.; Hide, D.; García-Cardeña, G.; García-Pagán, J.C.; Bosch, J.; Gracia-Sancho, J. The Transcription Factor KLF2 Mediates Hepatic Endothelial Protection and Paracrine Endothelial-Stellate Cell Deactivation Induced by Statins. J. Hepatol. 2013. [CrossRef]

196. Shay-Salit, A.; Shushy, M.; Wolfovitz, E.; Yahav, H.; Breviario, F.; Dejana, E.; Resnick, N. VEGF Receptor 2 and the Adherens Junction as a Mechanical Transducer in Vascular Endothelial Cells. Proc. Natl. Acad. Sci. USA 2002, 99, 9462-9467. [CrossRef]

197. Braet, F.; Shleper, M.; Paizi, M.; Brodsky, S.; Kopeiko, N.; Resnick, N.; Spira, G. Liver Sinusoidal Endothelial Cell Modulation upon Resection and Shear Stress in Vitro. Comp. Hepatol. 2004, 3. [CrossRef]

198. Roskams, T. Relationships Among Stellate Cell Activation, Progenitor Cells, and Hepatic Regeneration. Clin. Liver Dis. 2008. [CrossRef]

199. You, Q.; Holt, M.; Yin, H.; Li, G.; Hu, C.J.; Ju, C. Role of Hepatic Resident and Infiltrating Macrophages in Liver Repair after Acute Injury. Biochem. Pharmacol. 2013. [CrossRef]

200. Widmann, J.J.; Fahimi, H.D. Proliferation of Mononuclear Phagocytes (Kupffer Cells) and Endothelial Cells in Regenerating Rat Liver. A Light and Electron Microscopic Cytochemical Study. Am. J. Pathol. 1975, 80, 349.

201. Abshagen, K.; Eipel, C.; Kalff, J.C.; Menger, M.D.; Vollmar, B. Loss of NF-KB Activation in Kupffer Cell-Depleted Mice Impairs Liver Regeneration after Partial Hepatectomy. Am. J. Physiol. Gastrointest. Liver Physiol. 2007. [CrossRef]

202. Xu, C.S.; Jiang, Y.; Zhang, L.X.; Chang, C.F.; Wang, G.P.; Shi, R.J.; Yang, Y.J. The Role of Kupffer Cells in Rat Liver Regeneration Revealed by Cell-Specific Microarray Analysis. J. Cell. Biochem. 2012. [CrossRef]

203. Mabuchi, A.; Mullaney, I.; Sheard, P.W.; Hessian, P.A.; Mallard, B.L.; Tawadrous, M.N.; Zimmermann, A.; Senoo, H.; Wheatley, A.M. Role of Hepatic Stellate Cell/Hepatocyte Interaction and Activation of Hepatic Stellate Cells in the Early Phase of Liver Regeneration in the Rat. J. Hepatol. 2004. [CrossRef]

204. Manavski, Y.; Abel, T.; Hu, J.; Kleinlützum, D.; Buchholz, C.J.; Belz, C.; Augustin, H.G.; Boon, R.A.; Dimmeler, S. Endothelial Transcription Factor KLF2 Negatively Regulates Liver Regeneration via Induction of Activin A. Proc. Natl. Acad. Sci. USA 2017. [CrossRef] 
205. Sackey-Aboagye, B.; Olsen, A.L.; Mukherjee, S.M.; Ventriglia, A.; Yokosaki, Y.; Greenbaum, L.E.; Lee, G.Y.; Naga, H.; Wells, R.G. Fibronectin Extra Domain a Promotes Liver Sinusoid Repair Following Hepatectomy. PLoS ONE 2016, 11, e0163737. [CrossRef]

206. DeLeve, L.D.; Wang, X.; Wang, L. VEGF-Sdf1 Recruitment of CXCR7+ Bone Marrow Progenitors of Liver Sinusoidal Endothelial Cells Promotes Rat Liver Regeneration. Am. J. Physiol. Gastrointest. Liver Physiol. 2016, 310, G739-G746. [CrossRef]

207. Maher, J.J. Cell-Specific Expression of Hepatocyte Growth Factor in Liver: Upregulation in Sinusoidal Endothelial Cells after Carbon Tetrachloride. J. Clin. Investig. 1993, 91, 2244-2252. [CrossRef]

208. Nanji, A.A.; Tahan, S.R.; Wei, Y.; Sadrzadeh, S.M.H. Hepatic Sinusoidal Endothelial Cell G1/S Arrest Correlates with Severity of Alcoholic Liver Injury in the Rat. Gastroenterology 1994. [CrossRef]

209. LeCouter, J.; Moritz, D.R.; Li, B.; Phillips, G.L.; Liang, X.H.; Gerber, H.P.; Hillan, K.J.; Ferraral, N. Angiogenesis-Independent Endothelial Protection of Liver: Role of VEGFR-1. Science 2003. [CrossRef]

210. Wang, L.L.; Wang, X.; Wang, L.L.; Chiu, J.D.; Van De Ven, G.; Gaarde, W.A.; Deleve, L.D. Hepatic Vascular Endothelial Growth Factor Regulates Recruitment of Rat Liver Sinusoidal Endothelial Cell Progenitor Cells. Gastroenterology 2012. [CrossRef]

211. Wang, L.; Wang, X.; Xie, G.; Wang, L.; Hill, C.K.; DeLeve, L.D. Liver Sinusoidal Endothelial Cell Progenitor Cells Promote Liver Regeneration in Rats. J. Clin. Investig. 2012, 122, 1567-1573. [CrossRef]

212. Steffan, A.-M.; Gendrault, J.-L.; McCuskey, R.S.; McCuskey, P.A.; Kirn, A. Phagocytosis, an Unrecognized Property of Murine Endothelial Liver Cells. Hepatology 1986. [CrossRef]

213. Taniguchi, E.; Sakisaka, S.; Matsuo, K.; Tanikawa, K.; Sata, M. Expression and Role of Vascular Endothelial Growth Factor in Liver Regeneration after Partial Hepatectomy in Rats. J. Histochem. Cytochem. 2001. [CrossRef]

214. Xu, C.S.; Chen, X.G.; Chang, C.F.; Wang, G.P.; Wang, W.B.; Zhang, L.X.; Zhu, Q.S.; Wang, L. Analysis of Time-Course Gene Expression Profiles of Sinusoidal Endothelial Cells during Liver Regeneration in Rats. Mol. Cell. Biochem. 2011. [CrossRef]

215. Sato, T.; El-Assal, O.N.; Ono, T.; Yamanoi, A.; Kumar Dhar, D.; Nagasue, N. Sinusoidal Endothelial Cell Proliferation and Expression of Angiopoietin/Tie Family in Regenerating Rat Liver. J. Hepatol. 2001. [CrossRef]

216. Mochida, S.; Ishikawa, K.; Inao, M.; Shibuya, M.; Fujiwara, K. Increased Expressions of Vascular Endothelial Growth Factor and Its Receptors, Flt-1 and KDR/Flk-1, in Regenerating Rat Liver. Biochem. Biophys. Res. Commun. 1996. [CrossRef] [PubMed]

217. Shubham, S.; Kumar, D.; Rooge, S.; Maras, J.S.; Maheshwari, D.; Nautiyal, N.; Kumari, R.; Bhat, A.; Kumar, G.; Rastogi, A.; et al. Cellular and Functional Loss of Liver Endothelial Cells Correlates with Poor Hepatocyte Regeneration in Acute-on-Chronic Liver Failure. Hepatol. Int. 2019. [CrossRef] [PubMed]

218. Lao, Y.; Li, Y.; Zhang, P.; Shao, Q.; Lin, W.; Qiu, B.; Lv, Y.; Tang, L.; Su, S.; Zhang, H.; et al. Targeting Endothelial Erk1/2-Akt Axis as a Regeneration Strategy to Bypass Fibrosis during Chronic Liver Injury in Mice. Mol. Ther. 2018. [CrossRef] [PubMed]

219. Chung, A.S.; Ferrara, N. Developmental and Pathological Angiogenesis. Annu. Rev. Cell Dev. Biol. 2011. [CrossRef] [PubMed]

220. Asahara, T.; Murohara, T.; Sullivan, A.; Silver, M.; Van Der Zee, R.; Li, T.; Witzenbichler, B.; Schatteman, G.; Isner, J.M. Isolation of Putative Progenitor Endothelial Cells for Angiogenesis. Science 1997. [CrossRef]

221. Shi, Q.; Rafii, S.; Wu Hong-De, M.; Wijelath, E.S.; Yu, C.; Ishida, A.; Fujita, Y.; Kothari, S.; Mohle, R.; Sauvage, L.R.; et al. Evidence for Circulating Bone Marrow-Derived Endothelial Cells. Blood 1998, 92, 362-367. [CrossRef]

222. Peichev, M.; Naiyer, A.J.; Pereira, D.; Zhu, Z.; Lane, W.J.; Williams, M.; Oz, M.C.; Hicklin, D.J.; Witte, L.; Moore, M.A.S.; et al. Expression of VEGFR-2 and AC133 by Circulating Human CD34 + Cells Identifies a Population of Functional Endothelial Precursors. Blood 2000, 95, 952-958. [CrossRef]

223. Katagiri, H.; Kushida, Y.; Nojima, M.; Kuroda, Y.; Wakao, S.; Ishida, K.; Endo, F.; Kume, K.; Takahara, T.; Nitta, H.; et al. A Distinct Subpopulation of Bone Marrow Mesenchymal Stem Cells, Muse Cells, Directly Commit to the Replacement of Liver Components. Am. J. Transplant. 2016. [CrossRef]

224. Yu, Y.; Liang, Y.; Liu, X.; Yang, H.; Su, Y.; Xia, X.; Wang, H. Id1 Modulates Endothelial Progenitor Cells Function through Relieving the E2-2-Mediated Repression of FGFR1 and VEGFR2 in Vitro. Mol. Cell. Biochem. 2016. [CrossRef] [PubMed] 
225. Yu, Y.; Liang, Y.; Yin, C.; Liu, X.; Su, Y.; Zhang, L.; Wang, H. Inhibitor of DNA-Binding 1 Promotes Endothelial Progenitor Cell Proliferation and Migration by Suppressing E2-2 through the Helix-Loop-Helix Domain. Int. J. Mol. Med. 2016. [CrossRef] [PubMed]

226. Xia, X.; Yu, Y.; Zhang, L.; Ma, Y.; Wang, H. Inhibitor of DNA Binding 1 Regulates Cell Cycle Progression of Endothelial Progenitor Cells through Induction of Wnt2 Expression. Mol. Med. Rep. 2016. [CrossRef] [PubMed]

227. Harb, R.; Xie, G.; Lutzko, C.; Guo, Y.; Wang, X.; Hill, C.K.; Kanel, G.C.; DeLeve, L.D. Bone Marrow Progenitor Cells Repair Rat Hepatic Sinusoidal Endothelial Cells After Liver Injury. Gastroenterology 2009. [CrossRef]

228. Wang, X.; Maretti-Mira, A.C.; Wang, L.; DeLeve, L.D. Liver-Selective MMP-9 Inhibition in the Rat Eliminates Ischemia-Reperfusion Injury and Accelerates Liver Regeneration. Hepatology 2019. [CrossRef]

229. Bautch, V.L. Stem Cells and the Vasculature. Nat. Med. 2011. [CrossRef]

230. Medina, R.J.; Barber, C.L.; Sabatier, F.; Dignat-George, F.; Melero-Martin, J.M.; Khosrotehrani, K.; Ohneda, O.; Randi, A.M.; Chan, J.K.Y.; Yamaguchi, T.; et al. Endothelial Progenitors: A Consensus Statement on Nomenclature. Stem Cells Transl. Med. 2017. [CrossRef]

231. Dickson, I. Stem Cell Therapy for Liver Cirrhosis UnREALISTIC? Nat. Rev. Gastroenterol. Hepatol. 2018. [CrossRef]

232. Singhal, M.; Liu, X.; Inverso, D.; Jiang, K.; Dai, J.; He, H.; Bartels, S.; Li, W.; Abdul Pari, A.A.; Gengenbacher, N.; et al. Endothelial Cell Fitness Dictates the Source of Regenerating Liver Vasculature. J. Exp. Med. 2018. [CrossRef]

233. Sun, M.; Kisseleva, T. Reversibility of Liver Fibrosis. Clin. Res. Hepatol. Gastroenterol. 2015, S60-S63. [CrossRef]

234. Fernández Carrillo, C.; Lens, S.; Llop, E.; Pascasio, J.M.; Crespo, J.; Arenas, J.; Fernández, I.; Baliellas, C.; Carrión, J.A.; de la Mata, M.; et al. Treatment of Hepatitis C Virus Infection in Patients with Cirrhosis and Predictive Value of Model for End-Stage Liver Disease: Analysis of Data from the Hepa-C Registry. Hepatology 2017. [CrossRef] [PubMed]

235. Lens, S.; Alvarado, E.; Mariño, Z.; Martinez, J.; Londoño, M.; Llop, E.; Panero, C.; Torras, X.; Baiges, A.; Hernandez-gea, V.; et al. PS-150 Long-Term Impact of HCV Eradication after All-Oral Therapy in Patients with Clinical Significant Portal Hypertension. J. Hepatol. 2018, 68, S84. [CrossRef]

236. Mauro, E.; Crespo, G.; Montironi, C.; Londoño, M.-C.; Hernandez-Gea, V.; Ruiz, P.; Sastre, L.; Lombardo, J.; Mariño, Z.; Diaz, A.; et al. Portal Pressure and Liver Stiffness Measurements in the Prediction of Fibrosis Regression after SVR in Recurrent Hepatitis C Ezequiel. Hepatology 2017. [CrossRef]

237. Iredale, J.P.; Benyon, R.C.; Pickering, J.; McCullen, M.; Northrop, M.; Pawley, S.; Hovell, C.; Arthur, M.J. Mechanisms of Spontaneous Resolution of Rat Liver Fibrosis. Hepatic Stellate Cell Apoptosis and Reduced Hepatic Expression of Metalloproteinase Inhibitors. J. Clin. Investig. 1998. [CrossRef]

238. Troeger, J.S.; Mederacke, I.; Gwak, G.Y.; Dapito, D.H.; Mu, X.; Hsu, C.C.; Pradere, J.P.; Friedman, R.A.; Schwabe, R.F. Deactivation of Hepatic Stellate Cells during Liver Fibrosis Resolution in Mice. Gastroenterology 2012, 143. [CrossRef]

239. Issa, R.; Williams, E.; Trim, N.; Kendall, T.; Arthur, M.J.P.; Reichen, J.; Benyon, R.C.; Iredale, J.P. Apoptosis of Hepatic Stellate Cells: Involvement in Resolution of Biliary Fibrosis and Regulation by Soluble Growth Factors. Gut 2001. [CrossRef] [PubMed]

240. Iredale, J.P.; Bataller, R. Identifying Molecular Factors That Contribute to Resolution of Liver Fibrosis. Gastroenterology 2014, 1160-1164. [CrossRef] [PubMed]

241. Iredale, J.P. Models of Liver Fibrosis: Exploring the Dynamic Nature of Inflammation and Repair in a Solid Organ. J. Clin. Investig. 2007, 539-548. [CrossRef]

242. Iredale, J.P.; Thompson, A.; Henderson, N.C. Extracellular Matrix Degradation in Liver Fibrosis: Biochemistry and Regulation. Biochim. Biophys. Acta Mol. Basis Dis. 2013, 1832, 876-883. [CrossRef]

243. Campana, L.; Iredale, J.P. Regression of Liver Fibrosis. Semin. Liver Dis. 2017, 37, 1-10. [CrossRef]

244. Issa, R.; Zhou, X.; Constandinou, C.M.; Fallowfield, J.; Millward-Sadler, H.; Gaca, M.D.A.; Sands, E.; Suliman, I.; Trim, N.; Knorr, A.; et al. Spontaneous Recovery from Micronodular Cirrhosis: Evidence for Incomplete Resolution Associated with Matrix Cross-Linking. Gastroenterology 2004. [CrossRef] [PubMed]

245. Iredale, J.P. Tissue Inhibitors of Metalloproteinases in Liver Fibrosis. Int. J. Biochem. Cell Biol. 1997, 43-54. [CrossRef] 
246. Duffield, J.S.; Forbes, S.J.; Constandinou, C.M.; Clay, S.; Partolina, M.; Vuthoori, S.; Wu, S.; Lang, R.; Iredale, J.P.; Leibovich, S.; et al. Selective Depletion of Macrophages Reveals Distinct, Opposing Roles during Liver Injury and Repair. J. Clin. Investig. 2005. [CrossRef]

247. Ramachandran, P.; Pellicoro, A.; Vernon, M.A.; Boulter, L.; Aucott, R.L.; Ali, A.; Hartland, S.N.; Snowdon, V.K.; Cappon, A.; Gordon-Walker, T.T.; et al. Differential Ly-6C Expression Identifies the Recruited Macrophage Phenotype, Which Orchestrates the Regression of Murine Liver Fibrosis. Proc. Natl. Acad. Sci. USA 2012. [CrossRef]

248. Thomas, J.A.; Pope, C.; Wojtacha, D.; Robson, A.J.; Gordon-Walker, T.T.; Hartland, S.; Ramachandran, P.; Van Deemter, M.; Hume, D.A.; Iredale, J.P.; et al. Macrophage Therapy for Murine Liver Fibrosis Recruits Host Effector Cells Improving Fibrosis, Regeneration, and Function. Hepatology 2011, 53, 2003-2015. [CrossRef]

249. Kantari-Mimoun, C.; Krzywinska, E.; Castells, M.; Milien, C.; Klose, R.; Meinecke, A.K.; Lemberger, U.; Mathivet, T.; Gojkovic, M.; Schrödter, K.; et al. Boosting the Hypoxic Response in Myeloid Cells Accelerates Resolution of Fibrosis and Regeneration of the Liver in Mice. Oncotarget 2017, 8, 15085-15100. [CrossRef]

250. DeLeve, L.D. Liver Sinusoidal Endothelial Cells in Hepatic Fibrosis. Hepatology 2015, 61, 1740-1746. [CrossRef]

251. Malovic, I.; Sørensen, K.K.; Elvevold, K.H.; Nedredal, G.I.; Paulsen, S.; Erofeev, A.V.; Smedsrød, B.H.; McCourt, P.A.G. The Mannose Receptor on Murine Liver Sinusoidal Endothelial Cells Is the Main Denatured Collagen Clearance Receptor. Hepatology 2007, 45, 1454-1461. [CrossRef]

252. Hellevik, T.; Bondevik, A.; Smedsrød, B. Intracellular Fate of Endocytosed Collagen in Rat Liver Endothelial Cells. Exp. Cell Res. 1996, 223, 39-49. [CrossRef]

253. Smedsrod, B.; Johansson, S.; Pertoft, H. Studies in Vivo and in Vitro on the Uptake and Degradation of Soluble Collagen A1(I) Chains in Rat Liver Endothelial and Kupffer Cells. Biochem. J. 1985, 228, 415-424. [CrossRef]

254. Smedsrod, B. Receptor-Mediated Endocytosis of Connective Tissue Macromolecules in Liver Endothelial Cells. Scand. J. Clin. Lab. Investig. Suppl. 1990, 50, 148-151.

255. Smedsrod, B.; Melkko, J.; Risteli, L.; Risteli, J. Circulating C-Terminal Propeptide of Type I Procollagen Is Cleared Mainly via the Mannose Receptor in Liver Endothelial Cells. Biochem. J. 1990, 271, 345-350. [CrossRef] [PubMed]

256. Lee, H.S.; Choi, J.; Son, T.; Wee, H.J.; Bae, S.J.; Seo, J.H.; Park, J.H.; Ryu, S.H.; Lee, D.; Jang, M.K.; et al. Altered AKAP12 Expression in Portal Fibroblasts and Liver Sinusoids Mediates Transition from Hepatic Fibrogenesis to Fibrosis Resolution. Exp. Mol. Med. 2018, 50. [CrossRef] [PubMed]

257. Falkowski, M.; Schledzewski, K.; Hansen, B.; Goerdt, S. Expression of Stabilin-2, a Novel Fasciclin-like Hyaluronan Receptor Protein, in Murine Sinusoidal Endothelia, Avascular Tissues, and at Solid/ Liquid Interfaces. Histochem. Cell Biol. 2003, 120, 361-369. [CrossRef]

258. Zhou, B.; Weigel, J.A.; Fauss, L.; Weigel, P.H. Identification of the Hyaluronan Receptor for Endocytosis (HARE). J. Biol. Chem. 2000, 275, 37733-37741. [CrossRef]

259. Toriyabe, N.; Hayashi, Y.; Hyodo, M.; Harashima, H. Synthesis and Evaluation of Stearylated Hyaluronic Acid for the Active Delivery of Liposomes to Liver Endothelial Cells. Biol. Pharm. Bull. 2011, 34, 1084-1089. [CrossRef]

260. Takei, Y.; Maruyama, A.; Ferdous, A.; Nishimura, Y.; Kawano, S.; Ikejima, K.; Okumura, S.; Asayama, S.; Nogawa, M.; Hashimoto, M.; et al. Targeted Gene Delivery to Sinusoidal Endothelial Cells: DNA Nanoassociate Bearing Hyaluronan-Glycocalyx. FASEB J. 2004, 18, 699-701. [CrossRef]

261. Szafraniec, J.; Błazejczyk, A.; Kus, E.; Janik, M.; Zajac, G.; Wietrzyk, J.; Chlopicki, S.; Zapotoczny, S. Robust Oil-Core Nanocapsules with Hyaluronate-Based Shells as Promising Nanovehicles for Lipophilic Compounds. Nanoscale 2017, 9, 18867-18880. [CrossRef]

262. Kren, B.T.; Unger, G.M.; Sjeklocha, L.; Trossen, A.A.; Korman, V.; Diethelm-Okita, B.M.; Reding, M.T.; Steer, C.J. Nanocapsule-Delivered Sleeping Beauty Mediates Therapeutic Factor VIII Expression in Liver Sinusoidal Endothelial Cells of Hemophilia A Mice. J. Clin. Investig. 2009, 119, 2086-2099. [CrossRef]

263. Lee, H.; Mok, H.; Lee, S.; Oh, Y.K.; Park, T.G. Target-Specific Intracellular Delivery of SiRNA Using Degradable Hyaluronic Acid Nanogels. J. Control. Release 2007, 119, 245-252. [CrossRef]

264. Marquez, J.; Fernandez-Piñeiro, I.; Araúzo-Bravo, M.J.; Poschmann, G.; Stühler, K.; Khatib, A.M.; Sanchez, A.; Unda, F.; Ibarretxe, G.; Bernales, I.; et al. Targeting Liver Sinusoidal Endothelial Cells with MiR-20a-Loaded Nanoparticles Reduces Murine Colon Cancer Metastasis to the Liver. Int. J. Cancer 2018, 143, 709-719. [CrossRef] [PubMed] 
265. Hunt, N.J.; McCourt, P.A.G.; Le Couteur, D.G.; Cogger, V.C. Novel Targets for Delaying Aging: The Importance of the Liver and Advances in Drug Delivery. Adv. Drug Deliv. Rev. 2018, 39-49. [CrossRef] [PubMed]

266. Bartsch, M.; Weeke-Klimp, A.H.; Hoenselaar, E.P.D.; Stuart, M.C.A.; Meijer, D.K.F.; Scherphof, G.L.; Kamps, J.A.A.M. Stabilized Lipid Coated Lipoplexes for the Delivery of Antisense Oligonucleotides to Liver Endothelial Cells in Vitro and in Vivo. J. Drug Target. 2004, 12, 613-621. [CrossRef] [PubMed]

267. Bartsch, M.; Weeke-Klimp, A.H.; Morselt,H.W.M.; Kimpfler, A.; Ásgeirsdóttir, S.A.; Schubert, R.; Meijer, D.K.F.; Scherphof, G.L.; Kamps, J.A.A.M. Optimized Targeting of Polyethylene Glycol-Stabilized Anti-Intercellular Adhesion Molecule 1 Oligonucleotide/Lipid Particles to Liver Sinusoidal Endothelial Cells. Mol. Pharmacol. 2005, 67, 883-890. [CrossRef] [PubMed]

268. Hunt, N.J.; Lockwood, G.P.; Le Couteur, F.H.; McCourt, P.A.G.; Singla, N.; Kang, S.W.S.; Burgess, A.; Kuncic, Z.; Le Couteur, D.G.; Cogger, V.C. Rapid Intestinal Uptake and Targeted Delivery to the Liver Endothelium Using Orally Administered Silver Sulfide Quantum Dots. ACS Nano 2020, 14, 1492-1507. [CrossRef] [PubMed]

269. Liu, Q.; Wang, X.; Liu, X.; Kumar, S.; Gochman, G.; Ji, Y.; Liao, Y.P.; Chang, C.H.; Situ, W.; Lu, J.; et al. Use of Polymeric Nanoparticle Platform Targeting the Liver To Induce Treg-Mediated Antigen-Specific Immune Tolerance in a Pulmonary Allergen Sensitization Model. ACS Nano 2019, 13, 4778-4794. [CrossRef]

270. Yu, X.; Chen, L.; Liu, J.; Dai, B.; Xu, G.; Shen, G.; Luo, Q.; Zhang, Z. Immune Modulation of Liver Sinusoidal Endothelial Cells by Melittin Nanoparticles Suppresses Liver Metastasis. Nat. Commun. 2019, 10. [CrossRef]

271. Akhter, A.; Hayashi, Y.; Sakurai, Y.; Ohga, N.; Hida, K.; Harashima, H. A Liposomal Delivery System That Targets Liver Endothelial Cells Based on a New Peptide Motif Present in the ApoB-100 Sequence. Int. J. Pharm. 2013, 456, 195-201. [CrossRef]

272. Carambia, A.; Freund, B.; Schwinge, D.; Bruns, O.T.; Salmen, S.C.; Ittrich, H.; Reimer, R.; Heine, M.; Huber, S.; Waurisch, C.; et al. Nanoparticle-Based Autoantigen Delivery to Treg-Inducing Liver Sinusoidal Endothelial Cells Enables Control of Autoimmunity in Mice. J. Hepatol. 2015, 62, 1349-1356. [CrossRef]

273. Liang, X.; Grice, J.E.; Zhu, Y.; Liu, D.; Sanchez, W.Y.; Li, Z.; Crawford, D.H.G.; Le Couteur, D.G.; Cogger, V.C.; Liu, X.; et al. Intravital Multiphoton Imaging of the Selective Uptake of Water-Dispersible Quantum Dots into Sinusoidal Liver Cells. Small 2015, 11, 1711-1720. [CrossRef]

274. Bargheer, D.; Giemsa, A.; Freund, B.; Heine, M.; Waurisch, C.; Stachowski, G.M.; Hickey, S.G.; Eychmüller, A.; Heeren, J.; Nielsen, P. The Distribution and Degradation of Radiolabeled Superparamagnetic Iron Oxide Nanoparticles and Quantum Dots in Mice. Beilstein J. Nanotechnol. 2015, 6, 111-123. [CrossRef] [PubMed]

275. Sato, Y.; Hatakeyama, H.; Hyodo, M.; Harashima, H. Relationship Between the Physicochemical Properties of Lipid Nanoparticles and the Quality of SiRNA Delivery to Liver Cells. Mol. Ther. 2016, 24, 788-795. [CrossRef] [PubMed]

276. Sano, N.; Tamura, T.; Toriyabe, N.; Nowatari, T.; Nakayama, K.; Tanoi, T.; Murata, S.; Sakurai, Y.; Hyodo, M.; Fukunaga, K.; et al. New Drug Delivery System for Liver Sinusoidal Endothelial Cells for Ischemia-Reperfusion Injury. World J. Gastroenterol. 2015, 21, 12778-12786. [CrossRef] [PubMed]

277. Seki, E.; De Minicis, S.; Österreicher, C.H.; Kluwe, J.; Osawa, Y.; Brenner, D.A.; Schwabe, R.F. TLR4 Enhances TGF- $\beta$ Signaling and Hepatic Fibrosis. Nat. Med. 2007, 13, 1324-1332. [CrossRef]

278. Chauhan, A.K.; Motto, D.G.; Lamb, C.B.; Bergmeier, W.; Dockal, M.; Plaimauer, B.; Scheiflinger, F.; Ginsburg, D.; Wagner, D.D. Systemic Antithrombotic Effects of ADAMTS13. J. Exp. Med. 2006, 203, 767-776. [CrossRef]

279. Geys, L.; Bauters, D.; Roose, E.; Tersteeg, C.; Vanhoorelbeke, K.; Hoylaerts, M.F.; Lijnen, R.H.; Scroyen, I. ADAMTS13 Deficiency Promotes Microthrombosis in a Murine Model of Diet-Induced Liver Steatosis. Thromb. Haemost. 2017, 117, 19-26. [CrossRef]

280. Huang, Y.; Feng, H.; Kan, T.; Huang, B.; Zhang, M.; Li, Y.; Shi, C.; Wu, M.; Luo, Y.; Yang, J.; et al. Bevacizumab Attenuates Hepatic Fibrosis in Rats by Inhibiting Activation of Hepatic Stellate Cells. PLoS ONE 2013, 8, e73492. [CrossRef]

(C) 2020 by the authors. Licensee MDPI, Basel, Switzerland. This article is an open access article distributed under the terms and conditions of the Creative Commons Attribution (CC BY) license (http://creativecommons.org/licenses/by/4.0/). 